\title{
Management of myocardial revascularisation failure: an expert consensus document of the EAPCI
}

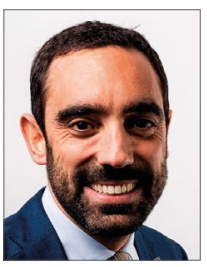

Giulio G. Stefanini ${ }^{1,2 *}, \mathrm{MD}, \mathrm{PhD}$; Fernando Alfonso ${ }^{3}, \mathrm{MD}, \mathrm{PhD}$; Emanuele Barbato ${ }^{4}, \mathrm{MD}, \mathrm{PhD}$; Robert A. Byrne ${ }^{5,6}, \mathrm{MB}, \mathrm{BCh}, \mathrm{PhD}$; Davide Capodanno ${ }^{7}, \mathrm{MD}, \mathrm{PhD}$; Roisin Colleran ${ }^{5,8}, \mathrm{MB}, \mathrm{BCh}$; Javier Escaned ${ }^{9}, \mathrm{MD}, \mathrm{PhD}$; Daniele Giacoppo ${ }^{10,11}$, MD; Vijay Kunadian ${ }^{12}$, MBBS, PhD; Alexandra Lansky ${ }^{13,14}$, MD; Julinda Mehilli ${ }^{15,16}$, MD; Franz-Josef Neumann ${ }^{17}$, MD; Damiano Regazzoli², MD; Jorge Sanz-Sánchez ${ }^{1}, \mathrm{MD}, \mathrm{PhD}$; William Wijns ${ }^{18}, \mathrm{MD}, \mathrm{PhD}$; Andreas Baumbach ${ }^{13,14}, \mathrm{MD}, \mathrm{PhD}$

The authors' affiliations can be found in the Appendix paragraph.

GUEST EDITOR: Alec Vahanian, MD, PhD; Department of Cardiology, Hôpital Bichat-Claude Bernard, and University Paris VII, Paris, France

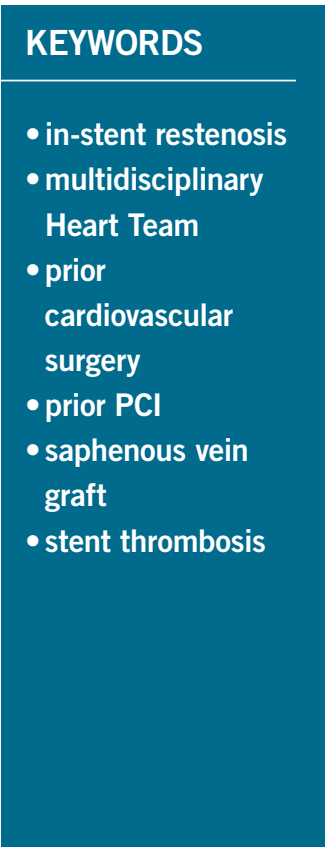

\section{Abstract}

Myocardial revascularisation represents the most frequently performed therapeutic intervention worldwide. Current percutaneous and surgical revascularisation techniques provide excellent short- and long-term clinical outcomes. However, despite the technological and procedural advances with the widespread use of drug-eluting stents and arterial bypass grafts in contemporary practice, a considerable proportion of patients require repeat revascularisation procedures during long-term follow-up. The need for repeat revascularisation has a major impact on patients' quality of life and is associated with a significant economic burden. This consensus document summarises the views on the management of myocardial revascularisation failure of an expert panel of the European Association of Percutaneous Cardiovascular Interventions (EAPCI). The present document provides a broad and pragmatic overview of the clinical management of myocardial revascularisation failure with a focus on the three key underlying mechanisms leading to repeat revascularisation: 1) failure of percutaneous coronary interventions, 2) failure of coronary artery bypass grafting, and 3) progression of coronary artery disease in native coronary segments previously untreated. The aim of the present position document is to provide a patient-oriented approach for the management of myocardial revascularisation failure.

*Corresponding author: Humanitas Clinical and Research Center IRCCS, Via Manzoni, 56, 20089 Rozzano, Milan, Italy. E-mail: giulio.stefanini@gmail.com 


$\begin{array}{ll}\text { Abbreviations } \\ \text { ACS } & \text { acute coronary syndrome } \\ \text { BID } & \text { bis in die } \\ \text { BMS } & \text { bare metal stent } \\ \text { CABG } & \text { coronary artery bypass grafting } \\ \text { CAD } & \text { coronary artery disease } \\ \text { CI } & \text { confidence interval } \\ \text { DAPT } & \text { dual antiplatelet treatment } \\ \text { DCB } & \text { drug-coated balloon(s) } \\ \text { DES } & \text { drug-eluting stent(s) } \\ \text { ECG } & \text { electrocardiogram } \\ \text { FFR } & \text { fractional flow reserve } \\ \text { HR } & \text { hazard ratio } \\ \text { ISR } & \text { in-stent restenosis } \\ \text { IVUS } & \text { intravascular ultrasound } \\ \text { LAD } & \text { left anterior descending artery } \\ \text { LIMA } & \text { left internal mammary artery } \\ \text { MI } & \text { myocardial infarction } \\ \text { OCT } & \text { optical coherence tomography } \\ \text { OR } & \text { odds ratio } \\ \text { PCI } & \text { percutaneous coronary intervention(s) } \\ \text { PROSPECT } & \text { Prospective Natural History Study of Coronary } \\ \text { RR } & \text { Atherosclerosis } \\ \text { TLR } & \text { risk ratio } \\ \end{array}$

\section{Introduction}

Myocardial revascularisation represents the most frequently performed therapeutic intervention worldwide ${ }^{1,2}$. Current revascularisation techniques provide excellent clinical outcomes during long-term follow-up ${ }^{1,3}$. However, approximately $20 \%$ of patients undergoing myocardial revascularisation require a repeat revascularisation procedure during the first five years of follow-up, with a higher risk after percutaneous coronary interventions (PCI) as compared with coronary artery bypass grafting $(\mathrm{CABG})^{4-7}$. The need for repeat revascularisation has a significant impact on quality of life and healthcare resources, and exposes patients to risks intrinsically related to repeat hospitalisations and invasive procedures $^{4,8,9}$. Moreover, patients requiring repeat revascularisation are characterised by a high cardiac risk profile, due to comorbidities and anatomical features ${ }^{7,10}$, rendering their clinical management a significant challenge in daily practice.

This document summarises the views on the management of myocardial revascularisation failure of an expert panel of the European Association of Percutaneous Cardiovascular Interventions (EAPCI). The committee members were proposed by the document chair and co-chair and approved by the EAPCI Scientific Documents and Initiatives Committee.

This document approaches the management of myocardial revascularisation failure from a patient-oriented perspective, based on the underlying mechanisms leading to the clinical need for repeat revascularisation - failure of $\mathrm{PCI}$, failure of $\mathrm{CABG}$, and progression of coronary artery disease (CAD) in native coronary segments previously untreated. The latter is not directly related to overt failure of a previous PCI or CABG. However, from a patient perspective, the need for a new revascularisation procedure represents a failure of the initial treatment strategy and should, therefore, be evaluated in the context of revascularisation failure.

This document has three key objectives: 1) to outline the different mechanisms underlying myocardial revascularisation failure; 2) to detail the specific challenges to the short- and long-term success of repeat revascularisation procedures; and 3) to delineate systematic and informed strategies aimed at increasing the safety and efficacy of these procedures.

Editorial, see page 865

\section{Failure of percutaneous coronary interventions}

The vast majority of PCI procedures include stent implantation. Stent thrombosis and restenosis are key mechanisms of stent failure requiring repeat revascularisation.

\section{STENT THROMBOSIS}

\section{EARLY STENT THROMBOSIS}

Early stent thrombosis is defined as stent thrombosis occurring within the first 30 days after stent implantation and is subclassified into acute (0-24 hours) and subacute ( $>24$ hours-30 days) stent thrombosis ${ }^{11}$. Early stent thrombosis is a relatively infrequent occurrence in contemporary clinical practice (Table 1) ${ }^{12}$. Most cases are related to mechanical or anatomical factors, in association with a thrombogenic milieu or an acute triggering event (Table 2).

\section{LATE AND VERY LATE STENT THROMBOSIS}

Late stent thrombosis is defined as stent thrombosis that occurs between 30 days and one year after stent implantation. Very late stent thrombosis is defined as stent thrombosis that occurs later than one year after stent implantation ${ }^{11}$.

In contemporary large-scale drug-eluting stent (DES) trials with broad inclusion criteria, stent thrombosis rates are low beyond 30 days after stent implantation (Table 1).

The risk factors and underlying mechanisms of late and very late stent thrombosis are summarised in Table 2.

\section{MANAGEMENT OF PATIENTS WITH STENT THROMBOSIS}

Most patients with stent thrombosis present with acute myocardial infarction (MI), with or without ST-segment elevation ${ }^{13}$. Accordingly, the principles of management are those recommended in relevant clinical practice guidelines ${ }^{14-16}$. Usually, patients with suspected ST should undergo urgent coronary angiography to confirm the diagnosis and treat the underlying cause.

Liberal use of intracoronary imaging ${ }^{17}$ - with intravascular ultrasound (IVUS) or optical coherence tomography (OCT) - is recommended by clinical practice guidelines, in order to detect and modify underlying mechanical factors, and to assess the contribution of concomitant restenosis or neoatherosclerosis to instent obstruction ${ }^{14}$.

In case of a completely occluded vessel, flow should be restored initially, and intravascular imaging should be performed afterwards. In addition to intracoronary imaging, radiological stent 
Table 1. Rates of stent thrombosis and TLR in selected contemporary large-scale all-comer clinical trials ${ }^{86-103 .}$

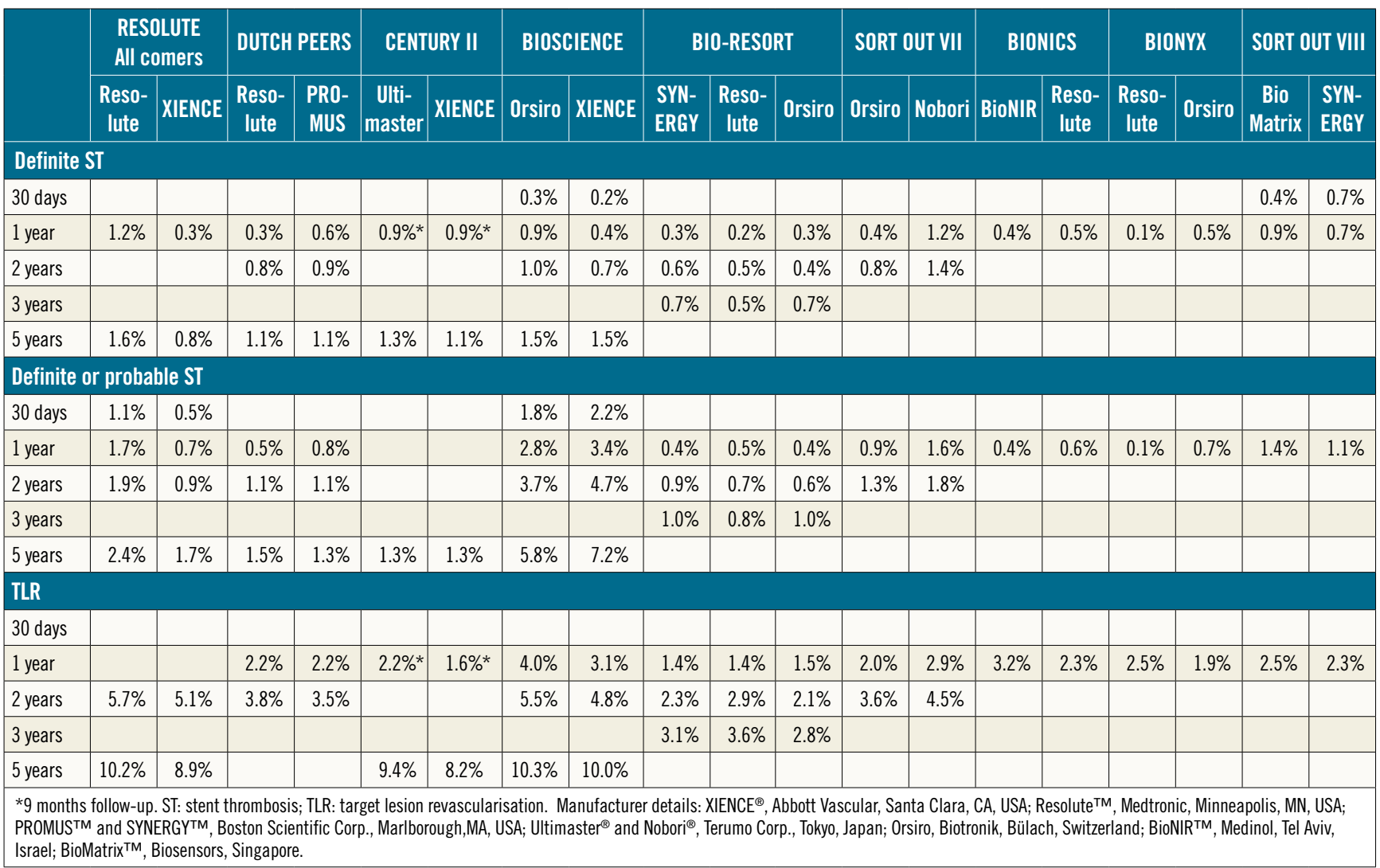

enhancement is a helpful method to diagnose loss of stent integrity or underexpansion ${ }^{18}$. Although routine thrombus aspiration is not recommended by current guidelines, it might be considered in selected cases of stent thrombosis with a large thrombus burden.
Similarly, glycoprotein IIb/IIIa receptor antagonists should be considered in view of the elevated prothrombotic milieu. Cangrelor use may be considered in patients not being treated with a $\mathrm{P}_{12}$ inhibitor at the time of stent thrombosis.

Table 2. Risk factors and underlying mechanism of stent thrombosis and in-stent restenosis.

\begin{tabular}{|c|c|c|c|c|c|}
\hline & \multicolumn{3}{|c|}{ Stent thrombosis ${ }^{12,13,17,104-109}$} & \multirow{2}{*}{ In-stent restenosis ${ }^{107,110-113}$} \\
\hline & & Early & Late & Very late & \\
\hline \multirow[t]{3}{*}{$\begin{array}{l}\text { Risk } \\
\text { factors }\end{array}$} & Patient-related & $\begin{array}{l}\text { - Acute clinical presentation } \\
\text { - Poor response to } \\
\text { antiplatelet treatment } \\
\text { - High on-treatment platelet } \\
\text { reactivity } \\
\text { - Current smoking } \\
\text { - Genetic variants* } \\
\text { - Diabetes mellitus } \\
\text { - LVEF }<40 \%\end{array}$ & $\begin{array}{l}\text { - Current smoking } \\
\text { - Multivessel disease } \\
\text { - Younger age } \\
\text { - LVEF }<40 \% \\
\text { - eGFR }<30 \mathrm{ml} /\left(\min \cdot \mathrm{m}^{2}\right)\end{array}$ & $\begin{array}{l}\text { - Current smoking } \\
\text { - Multivessel disease } \\
\text { - Younger age }\end{array}$ & $\begin{array}{l}\text { - Diabetes mellitus } \\
\text { - Prior bypass surgery }\end{array}$ \\
\hline & Lesion-related & $\begin{array}{l}\text { - LMCA or LAD lesion } \\
\text { - Residual dissection } \\
\text { - TIMI flow grade <3 } \\
\text { - Bifurcation lesion } \\
\text { - Type C lesions } \\
\text { - Severely calcified lesions }\end{array}$ & $\begin{array}{l}\text { - LAD lesion } \\
\text { - Bypass graft lesion } \\
\text { - Presence of thrombus } \\
\text { - Bifurcation lesion } \\
\text { - Severely calcified } \\
\text { lesions }\end{array}$ & $\begin{array}{l}\text { - LAD lesion } \\
\text { - Bypass graft lesion } \\
\text { - Presence of thrombus }\end{array}$ & $\begin{array}{l}\text { - Small vessel size } \\
\text { - Complex morphology } \\
\text { - Previous diffuse ISR } \\
\text { - Bifurcation lesion }\end{array}$ \\
\hline & Stent-related & $\begin{array}{l}\text { - Undersizing } \\
\text { - Overlapping stents }\end{array}$ & $\begin{array}{l}\text { - Long stent length } \\
\text { - Overlapping stents }\end{array}$ & $\begin{array}{l}\text { - Long stent length } \\
\text { - Overlapping stents }\end{array}$ & - Long stent length \\
\hline \multicolumn{2}{|c|}{ Underlying mechanisms } & $\begin{array}{l}\text { - Uncovered struts } \\
\text { - Stent underexpansion } \\
\text { - Malapposition }\end{array}$ & $\begin{array}{l}\text { - Uncovered struts } \\
\text { - Malapposition }\end{array}$ & $\begin{array}{l}\text { - Neoatherosclerosis } \\
\text { - Uncovered struts } \\
\text { - Malapposition }\end{array}$ & $\begin{array}{l}\text { - Neointimal hyperplasia } \\
\text { - Neoatherosclerosis } \\
\text { - Stent underexpansion } \\
\text { - Loss of mechanical integrity }\end{array}$ \\
\hline
\end{tabular}

${ }^{*}$ CYP2C19, ABCB1 3435 TT and ITGB3 PLA2. eGFR: estimated glomerular filtration rate; ISR: in-stent restenosis; LAD: left anterior descending artery; LMCA: left main coronary artery; LVEF: left ventricular ejection fraction; TIMI: Thrombolysis In Myocardial Infarction 
Identified factors likely to have contributed to stent thrombosis should be corrected (Figure 1). Patients with deficits in mechanical stent integrity - such as stent gap, stent fracture or longitudinal deformation - as well as those with residual edge disease or dissection should generally be treated with repeat stenting. Stent crush or collapse is very rare, but it may be seen in heavily calcified lesions or at ostial locations; it also mandates repeat stenting. Significant stent underexpansion or malapposition should be corrected with non-compliant balloon dilation, including use of balloons with very high rated burst pressure, as required. Intravascular lithotripsy may be considered for severe, otherwise non-dilatable stent underexpansion ${ }^{19}$. Following dilation of underexpanded stents, an additional stent may be considered, although systematic repeat stenting in such cases should be avoided, especially if there are already multiple stent layers.

Non-mechanical causes of stent thrombosis may predominate in some cases. These include insufficient platelet inhibition due to hyporesponsiveness, non-compliance to antiplatelet therapy, or interruption for unplanned or non-deferrable surgery. In the absence of clearly identifiable mechanical causes of stent thrombosis, it may be sufficient to dilate the thrombosed stent to restore blood flow and administer antithrombotic agents (e.g., glycoprotein receptor inhibitors, intravenous $\mathrm{P}_{2} \mathrm{Y}_{12}$ inhibitors). Subsequently, insufficient platelet inhibition must be evaluated. Use of point-ofcare phenotypic and genetic testing has been suggested in patients with stent thrombosis without an evident underlying mechanical cause $^{20,21}$. Assessment of dual antiplatelet treatment (DAPT) compliance is of paramount importance, especially within the first 30 days after $\mathrm{PCI}^{22}$. Prasugrel and ticagrelor are preferred over clopidogrel after an acute stent thrombosis ${ }^{14}$. Prolonged DAPT beyond 12 months should be considered in patients after a stent thrombosis, weighing their increased thrombotic risk against their bleeding risk ${ }^{23-25}$.

\section{STENT THROMBOSIS: WHAT TO DO}

- Intracoronary imaging with IVUS and/or OCT to identify factors likely to have contributed to stent thrombosis.

- PCI with DES in case of deficits in mechanical stent integrity (stent fracture or collapse).

- PCI with DES in case of residual edge disease or dissection.

- High-pressure non-compliant balloon dilation in case of stent underexpansion or malapposition.

- Assess adherence to antiplatelet therapy.

- Assess platelet reactivity with point-of-care assays in selected cases of acute stent thrombosis without a clearly identified mechanical cause.

- After PCI for stent thrombosis, dual antiplatelet therapy with aspirin 75-100 mg daily and prasugrel $10 \mathrm{mg}$ daily or ticagrelor $90 \mathrm{mg}$ BID for 12 months.

\section{STENT THROMBOSIS: WHAT NOT TO DO}

- Systematic repeat stenting in cases of stent underexpansion, especially in the presence of multiple stent layers.

\section{IN-STENT RESTENOSIS}

In-stent restenosis (ISR) is a response to vessel wall injury that results in excessive tissue formation (i.e., neointimal hyperplasia or neoatherosclerosis) in the stented segment. ISR is an angiographic diagnosis, defined as a diameter stenosis $>50 \%$ within the stented segment (i.e., the stent and a $5 \mathrm{~mm}$ border proximal or distal to the stent). Although DES were highly effective in reducing the risk of ISR compared with bare metal stents (BMS), ISR remains the most frequent cause of stent failure and the most common indication for target lesion revascularisation (TLR). Large-scale clinical trials of patients treated with contemporary DES with broad inclusion criteria report rates of clinical restenosis (i.e., clinically indicated TLR) of $<3 \%$ at one year and $10 \%$ at five years (Table 1). Of note,

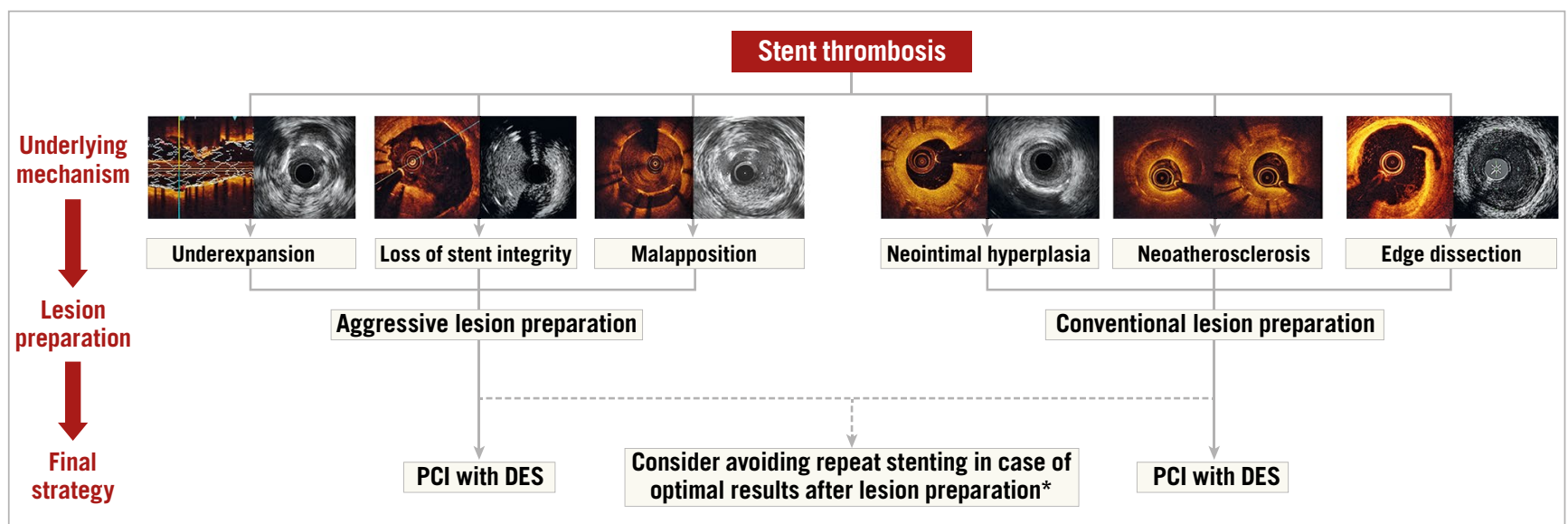

Figure 1. Algorithm for the management of stent thrombosis. *Avoiding stent implantation should be considered in cases with severe underexpansion or malapposition without further underlying mechanisms. In patients with stent thrombosis due to severe neointimal hyperplasia or neoatherosclerosis, PCI with DEB might be considered. Images were kindly provided by Drs Nicolas Amabile, Fernando Alfonso and Gennaro Sardella. DES: drug-eluting stent; PCI: percutaneous coronary intervention 
ISR presents as an acute coronary syndrome (ACS) in up to $20 \%$ of cases $^{26}$.

Clinical and angiographic factors predisposing to ISR are summarised in Table 2.

\section{MANAGEMENT OF PATIENTS WITH IN-STENT RESTENOSIS}

Treatment of ISR is challenging compared with treatment of de novo lesions, owing to relatively high recurrence rates ${ }^{27}$.

As the underlying substrate in ISR often overlaps with that of stent thrombosis, the principles of management are similar. However, while patients with thrombosis usually present with acute MI, patients with ISR may be asymptomatic and should only be treated in the presence of symptoms or objective evidence of ischaemia. In stable settings, if revascularisation is deemed necessary, the strategy should be carefully planned. As is the case with native coronary artery stenoses, when ISR angiographic severity is unclear, physiological guidance should be considered. If possible, the original lesion and the initial procedure (e.g., material used, maximum balloon pressures, challenges encountered, etc.) should be reviewed to identify potential technical issues that may need to be addressed during the repeat intervention. Intracoronary imaging of restenotic lesions, with IVUS or OCT, may provide insights into the mechanisms underlying ISR (Table 2), by identifying contributing mechanical factors as well as characterising the restenotic tissue type. Of note, in addition to intracoronary imaging, radiological stent enhancement is a helpful method to diagnose stent fracture or underexpansion in patients with ISR $^{18}$.

There are a number of technical issues that should be considered in the treatment of patients with ISR. Treatment should generally be focused on the stenosed segment rather than on the full length of the stented segment ${ }^{27}$. To prevent recurrent ISR, it is important to optimise the results of repeat procedures. Careful lesion preparation is required and mechanical issues should be recognised and corrected. Aggressive dilation of the underlying stent might be required, especially in underexpanded or collapsed stents, ideally using non-compliant balloons at high pressures (frequently $>18$ bar). Care should be taken to avoid geographic miss as this may lead to edge-related recurrence. Use of cutting balloons, or more flexible scoring balloons for lesion predilation, reduces slippage of the balloon out of the stent (so-called "water-melon seeding"), which may lead to stent edge dissections, with the potential for subsequent "candy wrapper" patterns of stent edge restenosis. These devices also incise the surface of the neointimal tissue, which theoretically may facilitate the uptake of drug delivery with drug-coated balloon (DCB) angioplasty or repeat DES implantation. Indeed, the ISAR-DESIRE 4 trial showed improved angiographic outcomes after lesion predilation with a scoring balloon compared with plain balloon angioplasty prior to $\mathrm{DCB}$ angioplasty ${ }^{28}$.

Occlusive ISR constitutes a challenging lesion subset for revascularisation. While the use of a contemporary approach to chronic total occlusion recanalisation is associated with improved procedural outcomes ${ }^{29}$, long-term results are worse than in de novo chronic total occlusion lesions, largely due to higher TLR rates ${ }^{30}$.

In the case of resistant stent underexpansion, very high-pressure ( 25 to 35 bar) balloons may be used. Modification of calcific plaques accounting for stent underexpansion can be performed with excimer laser atherectomy ${ }^{31}$ or intravascular lithotripsy, the latter also being useful in ISR with calcified neoatherosclerosis ${ }^{32,33}$. Rotational atherectomy (also termed "rotastenting") of undilatable underexpanded stents might be considered a second-line strategy but should be undertaken with caution due to the risk of serious complications ${ }^{34}$. Further study of the therapies discussed is required to confirm their potential benefits.

Following lesion preparation, a proportion of patients will require repeat stenting to correct loss of mechanical integrity of the underlying stent (e.g., due to fracture or gap or, in rare cases, with demonstrated stent collapse). In the remaining patients, after dilatation and correction of any stent underexpansion, a number of treatment options are available, but there is general consensus that additional treatment beyond mechanical dilatation is required as outcomes after plain balloon angioplasty alone are poor $^{35}$. The two most effective options are DCB angioplasty or repeat stenting with $\mathrm{DES}^{36,37}$. European clinical practice guidelines recommend the use of DES or DCB as first-line therapy in patients with ISR (class I recommendation and level of evidence A for both) ${ }^{14}$. Repeat stenting with DES seems to be marginally more effective in terms of angiographic recurrences and need for TLR as compared with DCB, particularly in patients with ISR of DES ${ }^{37,38}$. However, DCB avoid multiple metallic layers on the vessel wall, which may be of particular concern in patients with recurrent ISR. Accordingly, selection between the two strategies may be considered based on the individual characteristics of the patient and lesion to be treated. For instance, DCB may be preferred over DES in ISR of BMS, multiple metal layers, or large side branches. Conversely, DES may be preferred over DCB in lesions with stent fracture, diffuse ISR extending beyond the stent edges, or in case of significant residual dissection or impaired flow after a balloon-only approach (Figure 2). Some operators prefer repeat stenting in the case of ISR at the stent edge, though studies suggest that DCB appear to be as effective for ISR confined to the body of the stent as for those mainly involving its edges ${ }^{39,40}$.

Antiplatelet treatment for patients undergoing PCI for ISR should not differ from that in patients with a de novo lesion. When ISR clinically presents as chronic coronary syndrome, switching antiplatelet therapy is not recommended unless neoatherosclerosis with plaque rupture or erosion is identified by intracoronary imaging ${ }^{41}$.

\section{IN-STENT RESTENOSIS: WHAT TO DO}

- Intracoronary imaging with IVUS and/or OCT to detect stent-related mechanical problems leading to ISR.

- Aggressive predilation of the underlying stent with non-compliant balloons at high pressure, especially in underexpanded or collapsed stents. 


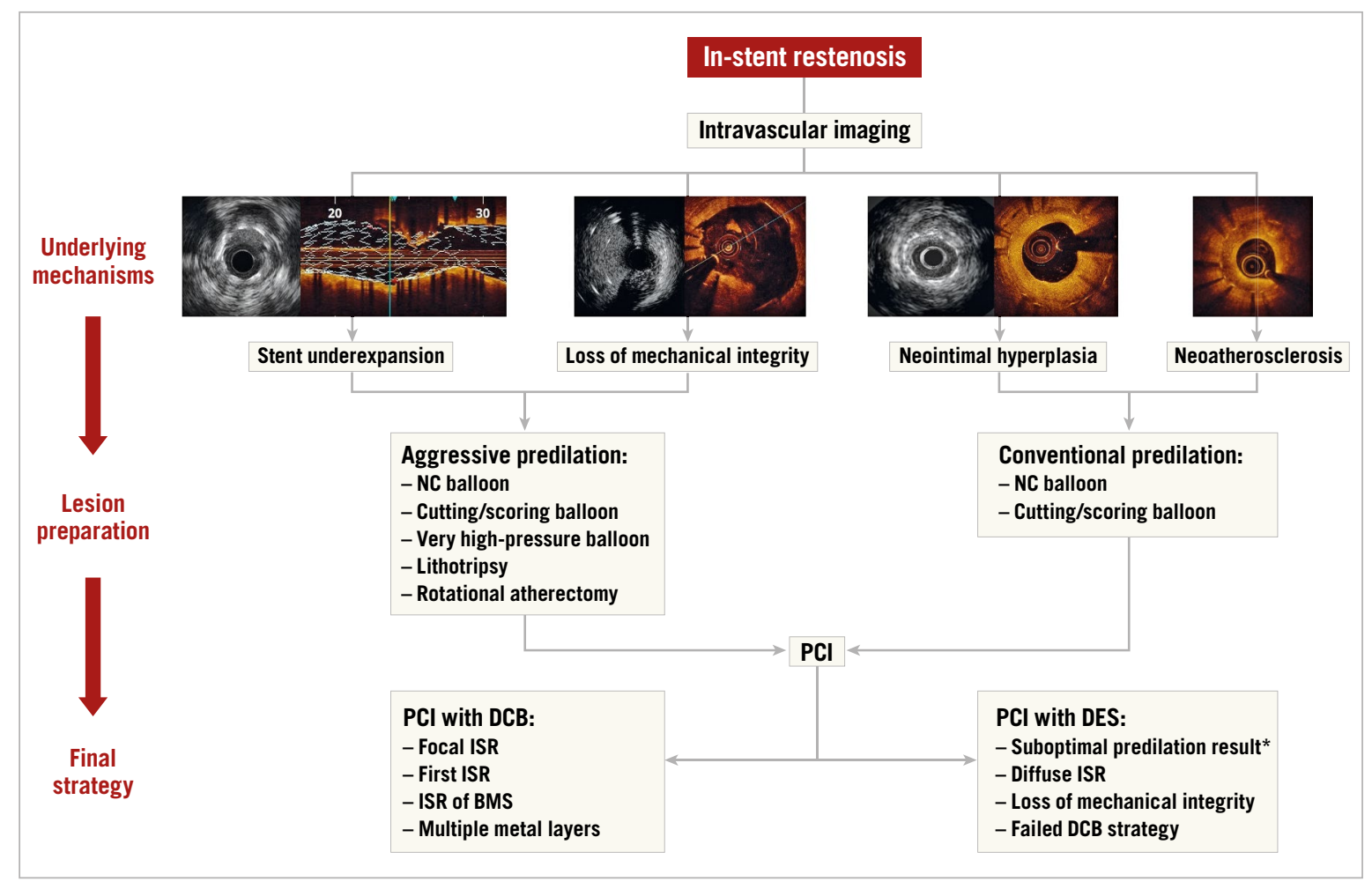

Figure 2. Algorithm for the management of in-stent restenosis. *In patients with edge dissection or acute recoil after lesion predilation, PCI with DES should be considered. Images were kindly provided by Drs Nicolas Amabile, Fernando Alfonso and Gennaro Sardella. BMS: bare metal stent; DCB: drug-coated balloon; DES: drug-eluting stent; ISR: in-stent restenosis; NC: non-compliant; PCI: percutaneous coronary intervention

- Lesion preparation with cutting balloons or scoring balloons in order to reduce balloon slippage outside the stent.

- Very high-pressure balloons, intravascular lithotripsy, excimer laser or rotational atherectomy in case of resistant stent underexpansion.

- After adequate lesion preparation, PCI with DES or DCB.

- DES preferred for suboptimal predilation results (residual stenosis $>50 \%$, large [large dissection defined if: longitudinal extension $>2 \mathrm{~mm}$, lateral extension $>60^{\circ}$ and involvement of medial or adventitia layers ${ }^{42}$ ] or flow-limiting dissections), diffuse ISR, loss of mechanical integrity, and failed DCB strategy. - DCB preferred for focal ISR, first ISR episode, ISR of BMS, and multiple metal layers.

- CABG or a conservative strategy instead of a new PCI attempt in patients with recurrent episodes of diffuse ISR, after a Heart Team discussion.

- After PCI for ACS due to underlying ISR, dual antiplatelet therapy with aspirin 75-100 mg daily and prasugrel $10 \mathrm{mg}$ daily or ticagrelor $90 \mathrm{mg}$ BID for 12 months.

\section{IN-STENT RESTENOSIS: WHAT NOT TO DO}

- Treatment of the full length of the initial stent instead of focusing on the stenosed segment.

- Plain balloon angioplasty-only strategy.

\section{ACUTE FUNCTIONAL FAILURE AFTER PCI}

Failing to identify haemodynamically significant coronary stenoses is one of the most common reasons portending revascularisation failure. Complementing coronary angiography with invasive functional assessment has received the highest level of recommendation by current guidelines to evaluate the haemodynamic relevance of intermediate-grade stenosis, when non-invasive evidence of ischaemia is not available ${ }^{14}$. Myocardial revascularisation aims to eliminate ischaemia and is, therefore, expected to normalise findings of invasive functional assessment.

While angiography is considered to have limited ability to assess the haemodynamic relevance of coronary lesions, the adequacy of acute results after PCI is still mainly assessed based on angiographic visual estimation only. However, early evidence with fractional flow reserve (FFR) suggested that suboptimal FFR after stenting is an independent predictor of adverse clinical outcomes at six months ${ }^{43}$. More recently, a prospective observational study including 574 consecutive patients (664 lesions) with FFR pre and post PCI evaluated clinical outcomes during a mean follow-up of $31 \pm 16$ months. Despite adequate angiographic result, 143 lesions ( $21 \%$ ) had post-PCI FFR values within the ischaemic range (FFR $\leq 0.80)^{44}$.

A meta-analysis that synthesised evidence from 59 observational (prospective and retrospective) studies evaluating the relationship 
between post-PCI FFR and clinical outcomes found a normal distribution of post-PCI FFR values, with a mean of $0.90 \pm 0.04$, and indicated that post-PCI FFR values appear to be related to the risk of repeat revascularisation (OR 0.43, 95\% CI: 0.34-0.56) and major adverse cardiac events (OR 0.71, 95\% CI: 0.59-0.85) during follow-up ${ }^{45}$. A threshold of final FFR $<0.90$ has been proposed to define a suboptimal result after stenting ${ }^{46}$.

Several investigations showed that additional interventions may optimise the acute result in patients with suboptimal post-PCI FFR $^{44,46,47}$. A recent prospective small-scale study suggested that intracoronary imaging with OCT may reveal potentially treatable causes (i.e., stent underexpansion, incomplete lesion coverage, stent malapposition, edge dissection, or tissue protrusion), allowing optimisation of the post-PCI functional result ${ }^{46}$. However, whether additional interventions based on post-PCI functional assessment have a significant impact on clinical outcomes has not been clearly determined ${ }^{48}$.

\section{ACUTE FUNCTIONAL FAILURE: WHAT TO DO}

- Repeat invasive functional assessment after stenting when already used to assess the haemodynamic relevance of the treated lesion.

- Attempt to identify reasons for suboptimal (i.e., FFR <0.90) invasive functional assessment post PCI, possibly with the use of intracoronary imaging.

\section{Failure of coronary artery bypass grafting}

Surgical graft failure is frequently observed with increasing time after CABG. Graft failure after use of saphenous vein grafts is as high as $50 \%$ at 10 years, with vein graft occlusion rates of up to $27 \%$ within the first year after $\mathrm{CABG}^{49-51}$. Within the first month after surgery, the causes of graft failure are mostly related to the surgical technique and flow pattern-related thrombotic complications, while graft failure thereafter is characterised by neointimal hyperplasia and accelerated progression of $\mathrm{CAD}^{52-54}$.

\section{ACUTE GRAFT FAILURE ( $<1$ MONTH AFTER SURGERY)}

Acute graft failure can be due to graft dissection, kinking or twisting, anastomotic technical errors, impaired vessel run-off into the native coronary artery, competitive flow from the native coronary artery, or graft thrombosis. In a study of 366 patients with routine post-CABG angiography, $12.2 \%$ of the grafts were found to have relevant angiographic defects requiring a minor adjustment of the graft in $2.8 \%$, an anastomosis revision in $3.4 \%$, and intraoperative open-chest PCI in $6.0 \%{ }^{52}$. Because of the logistic issues associated with routine direct postoperative angiography, intraoperative transit-time flow measurements and high-frequency epicardial ultrasound have been used to detect causes of graft failure before chest closure, allowing the opportunity for revision before myocardial ischaemia occurs or progresses.

When clinically relevant, acute graft failure may result in MI with a subsequent risk of mortality. The suspicion of early graft failure should arise in the presence of sudden clinical deterioration as indicated by electrocardiogram (ECG) signs of ischaemia, ventricular arrhythmias, biomarker changes, new wall motion abnormalities, or haemodynamic instability. Due to the low specificity of ECG changes and echocardiographic wall motion abnormalities during the postoperative course and the delay in appearance of biomarker changes, careful assessment of all variables will influence the decision making for angiographic evaluation ${ }^{14}$.

Despite the fact that arterial grafting is recommended by current guidelines on myocardial revascularisation ${ }^{14}$, vein grafts continue to be used in larger numbers than arterial grafts, despite having lower long-term patency rates ${ }^{1}$. Arterial grafts tend to be reserved for the prognostically most important areas of myocardium (e.g., the left internal mammary artery [LIMA] anastomosis to the left anterior descending artery [LAD]). Acute arterial graft failure, therefore, typically has a more severe clinical presentation than vein graft failure, while the latter more often occurs subclinically. An observational study showed that acute graft failure of the LIMA-to-LAD anastomosis warranted reintervention in $80 \%$ of patients, while acute vein graft failure was treated conservatively in approximately $50 \%$ of patients ${ }^{55}$.

\section{MANAGEMENT OF ACUTE GRAFT FAILURE}

Angiographic assessment is recommended if there is a suspicion of acute graft failure early postoperatively, and is performed in about $1-5 \%$ of patients ${ }^{55-58}$. In a recent meta-analysis of nine studies and 1,104 patients with suspected perioperative MI after CABG, acute graft failure was diagnosed in $62.1 \%$ of patients ${ }^{59}$. Incomplete revascularisation was the cause of the MI in $6.1 \%$ of patients, and $3.5 \%$ of patients had a native coronary artery as the culprit. Remarkably, in $31.6 \%$ of patients no cause of perioperative MI could be identified. In this context, it is important to underscore that haziness at the anastomosis in this acute period may be difficult to interpret and may not be related to the clinical problem.

The treatment strategy for acute graft failure should be made in an ad hoc Heart Team meeting. As summarised in Figure 3, a number of parameters should be considered in the decisionmaking process such as the technical reason for acute failure (i.e., problems related with the suture), age and risk profile of the patient, the patient's clinical condition (e.g., haemodynamic status and inotropic support), pre-CABG native vessel CAD and coronary anatomy, extent and timing of ischaemia, graft configuration, and extent of myocardium at risk.

In the setting of acute graft failure, emergency PCI may limit the extent of infarction. Current clinical guidelines advocate that PCI should be the preferred strategy in cases of acute graft failure where the anatomy is suitable ${ }^{14}$. In such cases, the target for PCI should be the native vessel or the internal mammary artery (IMA) graft, while an acutely occluded vein graft and any anastomotic site should be avoided, if possible, due to concerns regarding fragility of the new anastomosis as well as the risk of embolisation and perforation. The impact of in-hospital PCI following CABG was investigated in a retrospective study in which patients with acute coronary ischaemia requiring PCI after CABG $(\mathrm{N}=14,323)$ 


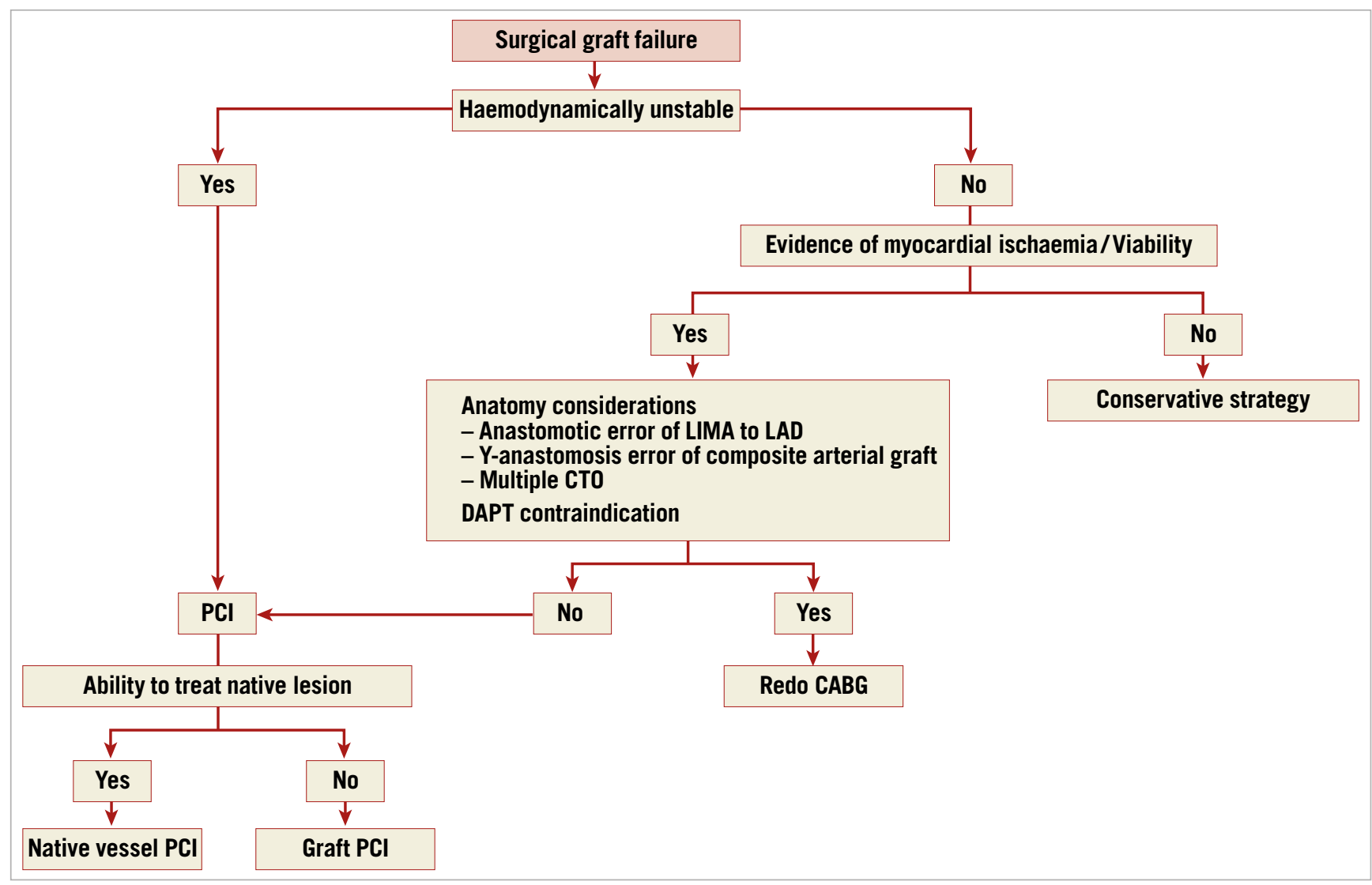

Figure 3. Algorithm for the management of patients with surgical graft failure. CTO: chronic total occlusion; DAPT: dual antiplatelet therapy; LAD: left anterior descending artery; LIMA: left internal mammary artery; PCI: percutaneous coronary intervention

were compared with those who did not undergo PCI $(\mathrm{N}=540,664)$. Post-CABG PCI was associated with an increased risk of unadjusted in-hospital mortality (5.1\% vs $2.7 \%$; $<<0.001)$, higher rates of stroke $(2.1 \%$ vs $1.6 \% ; \mathrm{p}<0.001)$, acute kidney injury $(16 \%$ vs $12.3 \% ; \mathrm{p}<0.001$ ), and a $50 \%$ cost increase ${ }^{60}$.

Redo CABG should be preferred when the anatomy is unsuitable for PCI, when an anastomotic error is evident, or when several important grafts are occluded ${ }^{14}$. Conservative treatment should be considered in cases where diagnosis has been delayed and viability is expected to be limited. In asymptomatic patients, repeat revascularisation should be considered if the failed graft supplies a large territory of myocardium.

\section{ACUTE GRAFT FAILURE: WHAT TO DO}

- Coronary angiography after CABG in patients with sudden clinical deterioration indicated by:

- symptoms of ischaemia and/or abnormal biomarkers suggestive of perioperative MI;

- ischaemic ECG changes indicating a large area of myocardium at risk;

- new significant wall motion abnormalities;

- haemodynamic instability.
- Emergency redo CABG or PCI decided upon by ad hoc consultation in the Heart Team, based on the feasibility of revascularisation, area at risk, comorbidities, and clinical status.

- PCI of the native vessel rather than PCI of the graft.

- Conservative treatment in graft failure cases where diagnosis has been delayed and viability is expected to be limited.

- In asymptomatic patients, repeat revascularisation if the failed graft supplies a large territory of myocardium.

\section{ACUTE GRAFT FAILURE: WHAT NOT TO DO}

- PCI in case of unsuitable anatomy, anastomotic error of the LIMA to LAD or at the Y-anastomosis of a composite arterial graft.

\section{LATE GRAFT FAILURE ( $>1$ MONTH AFTER CABG)}

As the time from surgery increases, vein grafts become prone to a process of aggressive and accelerated atherosclerosis. This results in mostly diffuse soft lipid-rich atherosclerotic plaques with extensive necrotic cores with or without intraplaque haemorrhage prone to rupture and downstream embolisation ${ }^{53,54}$.

Clinically relevant late graft failure presents mostly in the form of stable or unstable angina pectoris ${ }^{61-64}$. 


\section{MANAGEMENT OF LATE GRAFT FAILURE}

A number of critical issues should be considered when treating patients with degenerated grafts, including whether to perform redo $\mathrm{CABG}$ or $\mathrm{PCI}$, whether to treat native arteries or degenerated grafts, and the risk of distal embolisation in case of graft intervention.

PCI is considered the treatment of choice in case of late graft failure. Randomised comparisons between redo CABG and PCI, however, are lacking, partly due to patients' unwillingness to be allocated to redo $\mathrm{CABG}^{65}$. In a subgroup analysis of patients with late graft failure from the AWESOME trial and registry, redo CABG surgery was associated with higher periprocedural mortality as compared with PCI $^{65}$. Therefore, redo CABG surgery is recommended only in case of extensive native CAD with multiple graft occlusion, particularly in the absence of patent arterial grafts ${ }^{14}$.

PCI of vein grafts is considered a high-risk intervention due to an increased risk of slow/no-reflow related to distal embolisation of the friable atheroma, depending on the degree of graft degeneration $^{66,67}$. Embolic protection devices have been proposed to prevent distal embolisation ${ }^{68,69}$. A randomised trial performed in early 2000 showed a significant benefit of embolic protection devices in PCI of vein grafts ${ }^{68}$. A similar trend was seen in a subsequent randomised trial that was underpowered due to premature termination ${ }^{69}$. However, a meta-analysis of 52,893 patients enrolled in these randomised trials and in more recent observational studies did not suggest a benefit of routine use of embolic protection devices in PCI of vein grafts $^{70}$.

Several randomised trials have compared DES with BMS in vein graft lesions ${ }^{64}$. In a meta-analysis of randomised evidence, no differences between DES and BMS were observed in terms of all-cause death (RR 1.06, 95\% CI: 0.76-1.48), MI (RR 0.81, 95\% CI: 0.50-1.29), target vessel revascularisation (RR 0.73, 95\% CI: $0.48-1.11$ ) and TLR (RR 1.05, 95\% CI: 0.76-1.43) at longest follow-up ${ }^{64}$. In the ISAR-CABG trial, DES use was associated with a significantly lower risk of TLR during the first year of follow-up (HR 0.49, 95\% CI: 0.28-0.86) which was offset by a higher risk between one and five years (HR 2.10, 95\% CI: 1.37-3.22) as compared to BMS, with a significant interaction between treatment effect and time $\left(\mathrm{p}_{\text {interaction }}<0.001\right)^{62,63}$.

PCI of vein grafts is associated with a higher risk of adverse events as compared to PCI of native coronary arteries among patients with late graft failure ${ }^{71}$. In a registry of 11,118 veterans, PCI of vein grafts was associated with a significantly higher risk of mortality (adjusted HR 1.30, 95\% CI: 1.18-1.42), MI (adjusted HR 1.61, 95\% CI: 1.43-1.82) and repeat revascularisation (adjusted HR $1.69,95 \%$ CI: $1.50-1.71$ ) as compared to PCI of native arteries during a median follow-up of three years ${ }^{71}$.

Although available evidence clearly supports PCI of the native artery in case of late graft failure, anatomical complexities - such as multiple chronic total occlusions of native arteries - might limit the success of such a strategy, forcing interventionalists to treat degenerated grafts instead. Despite improvements in recanalisation techniques and available dedicated tools, previous $\mathrm{CABG}$ surgery remains one of the most important predictors of PCI failure in chronic total occlusions ${ }^{72}$. Therefore, the decision to treat native artery lesions or surgical grafts depends on CAD anatomical complexity and the interventionalists' expertise in complex PCI, seeking the most complete revascularisation. The decision should be made on an individual patient basis, giving priority to PCI of native arteries.

\section{LATE GRAFT FAILURE: WHAT TO DO}

- PCI as first choice over redo $\mathrm{CABG}$ for late graft failure.

- PCI of the native vessel rather than PCI of the graft.

- PCI strategy based on operator experience in complex PCI.

- Distal protection devices for PCI of vein graft lesions with diffused degeneration.

- IMA for redo CABG in patients in whom the IMA was not used previously.

- Redo CABG in patients without a patent IMA graft to the LAD, after checking its patency.

- Redo CABG in case of extensive native CAD, anatomically unsuitable for PCI, in the absence of patent grafts (especially arterial).

\section{LATE GRAFT FAILURE: WHAT NOT TO DO}

- Routine use of embolic protection devices for PCI of vein grafts.

- Plain balloon only for PCI of the graft.

\section{REPEAT REVASCULARISATION DUE TO PROGRESSION OF CAD}

CAD progression in native coronary segments previously untreated is the primary cause of repeat procedures after myocardial revascularisation.

\section{NATIVE CAD PROGRESSION AFTER PCI}

Disease progression is responsible for a relevant proportion of repeat revascularisation procedures after $\mathrm{PCI}^{6}$, although the incidence varies based on the clinical and anatomic characteristics of the population studied. The Prospective Natural History Study of Coronary Atherosclerosis (PROSPECT) studied the relative contribution of events related to the initially treated lesion (culprit lesion) and events related to $\mathrm{CAD}$ progression in non-culprit sites among 697 patients with ACS undergoing $\mathrm{PCI}^{73}$. The cumulative rate of major adverse cardiac events - a composite of cardiac death, arrest, MI, and hospitalisation for angina - was $20.4 \%$ at three years, with $12.9 \%$ of events related to the culprit lesion and $11.6 \%$ of events due to CAD progression at non-culprit sites. Overall, $65 \%$ of all events occurred within one year after PCI, with a relatively equal distribution between events related to the culprit lesion and those related to CAD progression. The overall repeat revascularisation rate was $17.1 \%$ at three years, with an equal contribution of events related to the culprit lesion and those related to CAD progression.

Predictors of $\mathrm{CAD}$ progression in previously untreated native coronary segments include clinical and angiographic factors that are largely overlapping with predictors of PCI and CABG failure, 
such as age, diabetes mellitus, complex coronary anatomy, extent of CAD, small vessel CAD, and previous PCI of vein grafts or ostial lesions ${ }^{6,74}$.

\section{NATIVE CAD PROGRESSION AFTER CABG}

Current recommendations for $\mathrm{CABG}$ inherently select patients at higher risk for native $\mathrm{CAD}$ progression. These include patients with multivessel CAD, high anatomical complexity and extent of $\mathrm{CAD}$, and coexistence of multiple comorbidities including diabetes mellitus, reduced left ventricular ejection fraction, and chronic kidney disease. Historical evidence indicates that accelerated CAD progression occurs up to tenfold more frequently in non-obstructive atherosclerotic lesions in bypassed coronary arteries compared with similar lesions in non-bypassed vessels at three years after $\mathrm{CABG}^{75}$. In another study, the risk of CAD progression was twice as high in arteries with patent grafts as compared to those with closed grafts, with the majority of grafted arteries with CAD progression being completely occluded. A more recent analysis of contemporary surgical techniques showed similar results, with development of a new chronic total occlusion in a native coronary artery in $>40 \%$ of patients within one year after CABG, strongly predicted by a severe $(>90 \%)$ proximal stenosis in the same vessel $^{76}$.

\section{GENERAL PRINCIPLES FOR MANAGEMENT OF CAD PROGRESSION}

In case of CAD progression in previously untreated native coronary segments following revascularisation, treatment recommendations should be based on symptoms and evidence of myocardial ischaemia. In this context, optimal medical therapy plays a pivotal role not only to reduce the risk of CAD progression but also for an initial management of patients with evidence of CAD progression. We refer to relevant clinical practice guidelines for a comprehensive assessment on recommendations for optimal medical management, which represents the cornerstone for prevention and treatment of CAD progression ${ }^{14,77,78}$. The interventional management of CAD progression differs according to the initial revascularisation modality.

\section{MANAGEMENT OF CAD PROGRESSION AFTER PCI}

In contemporary large-scale PCI trials, up to one third of patients enrolled were previously treated with $\mathrm{PCI}^{79-81}$. Percutaneous treatment of CAD progression after a previous PCI is generally reasonable. A surgical revascularisation strategy may be appropriate in case of CAD progression involving proximal segments of major coronary arteries or multivessel disease involving the left main or proximal LAD. A large registry that evaluated outcomes of patients with previous PCI undergoing CABG showed that early mortality and adverse ischaemic events did not significantly increase in patients with single or multiple previous PCI procedures ${ }^{82}$. Therefore, a strategy based on clinical and anatomical factors similar to that for patients with a first diagnosis of CAD is recommended in patients with CAD progression after PCI (Figure 4). MANAGEMENT OF CAD PROGRESSION AFTER CABG

Repeat revascularisation procedures after CABG are typically performed in older patients with more comorbidities and more complex coronary anatomy as compared to patients with a first

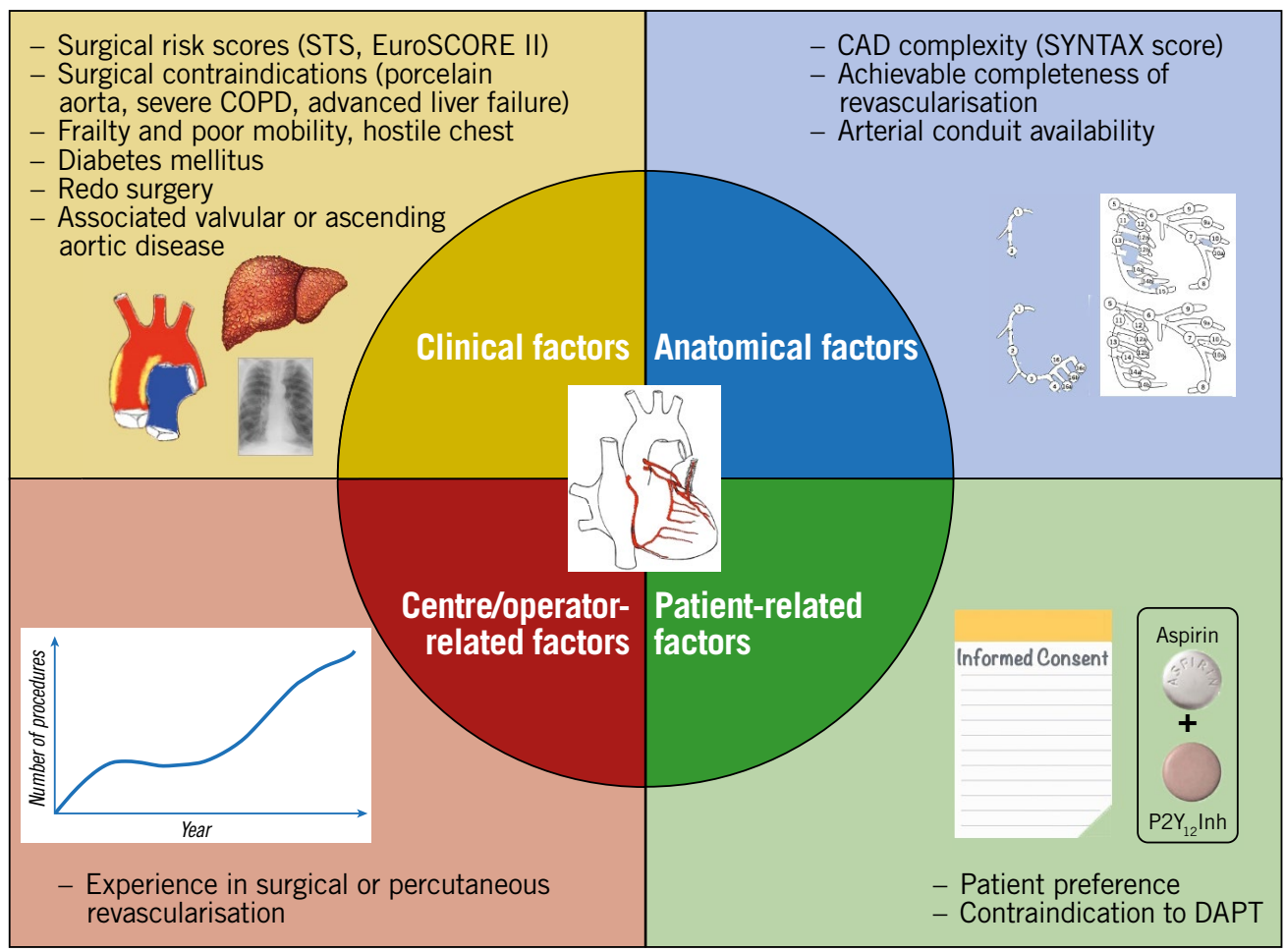

Figure 4. Factors that may guide revascularisation strategy for CAD progression. CAD: coronary artery disease; COPD: chronic obstructive pulmonary disease; DAPT: dual antiplatelet therapy; STS: Society of Thoracic Surgeons 
diagnosis of CAD. Furthermore, in these patients arterial conduits tend to be less frequently available, having already been used $^{83}$. Therefore, redo CABG is associated with increased procedural risks and worse clinical outcomes compared with a first CABG. Recent evidence indicates a trend towards a decreased risk of adverse events in patients treated with PCI coupled with an increase in PCI use in this setting ${ }^{66,84}$. In view of the paucity of available comparative effectiveness evidence, in these patients the selection of the repeat revascularisation strategy should be based on the assessment of clinical and anatomical risk profiles on an individual patient basis in discussion within the Heart Team (Figure 3, Figure 4) ${ }^{65,85}$.

\section{CAD PROGRESSION: WHAT TO DO}

- Repeat revascularisation in patients with evidence of CAD progression and with a large area of ischaemia or severe symptoms despite medical therapy.

- Base the selection of the repeat revascularisation strategy on the assessment of clinical and anatomical risk profiles on an individual basis in the context of the Heart Team.

- If considered safe, PCI with DES as first choice over CABG.

- IMA for redo CABG in patients in whom the IMA was not used previously.

- Redo CABG in patients without a patent IMA graft to the LAD.

CAD PROGRESSION: WHAT NOT TO DO

- Routine invasive angiography tests in asymptomatic patients with prior revascularisation.

- Routine ad hoc PCI in patients with progression of CAD after CABG.

\section{Conclusions}

Current percutaneous and surgical revascularisation techniques are associated with excellent procedural and long-term clinical outcomes. However, a considerable proportion of patients require repeat revascularisation procedures during long-term followup due to failure of the initial revascularisation - either PCI or CABG - or progression of disease in previously untreated coronary segments. This document provides evidence-based guidance for the management of myocardial revascularisation failure based on the underlying mechanism, the timing and the clinical and angiographic characteristics of individual patients.

\section{Appendix. Authors' affiliations}

1. Department of Biomedical Sciences, Humanitas University, Pieve Emanuele-Milan, Milan, Italy; 2. Humanitas Clinical and Research Center IRCCS, Rozzano, Milan, Italy; 3. Cardiac Department, Hospital Universitario de La Princesa, IIS-IP, CIBER-CV, Universidad Autónoma de Madrid, Madrid, Spain; 4. Department of Advanced Biomedical Sciences, University Federico II, Naples, Italy; 5. Dublin Cardiovascular Research Institute, Mater Private Hospital, Dublin, Ireland; 6. School of
Pharmacy and Biomolecular Sciences, Royal College of Surgeons in Ireland, Dublin, Ireland; 7. Division of Cardiology, AziendaOspedaliero-Universitaria "Policlinico G. Rodolico - San Marco", University of Catania, Catania, Italy; 8. Department of Cardiovascular Diseases, Deutsches Herzzentrum München, Technische Universität München, Munich, Germany; 9. Hospital Clinico San Carlos IDISSC, Complutense University of Madrid, Madrid, Spain; 10. Alto Vicentino Hospital, Vicenza, Italy; 11. Deutsches Herzzentrum München, Munich, Germany; 12. Translational and Clinical Research Institute, Faculty of Medical Sciences, Newcastle University, and Freeman Hospital, Newcastle upon Tyne Hospitals NHS Foundation Trust, Newcastle upon Tyne, United Kingdom; 13. Division of Cardiovascular Medicine, Yale University School of Medicine, New Haven, CT, USA; 14. Centre for Cardiovascular Medicine and Devices, William Harvey Research Institute, Queen Mary University of London, and Barts Heart Centre London, London, United Kingdom; 15. Medizinische Klinik und Poliklinik I, Klinikum der Universität München, Ludwig-Maximilians-Universität, Munich, Germany; 16. German Centre for Cardiovascular Research, partner site Munich Heart Alliance, Munich, Germany; 17. Department of Cardiology and Angiology II, University Heart Centre Freiburg-Bad Krozingen, Bad Krozingen, Germany; 18. The Lambe Institute for Translational Medicine and Curam, Saolta University Healthcare Group, National University of Ireland Galway, Galway, Ireland.

\section{Guest Editor}

This paper was guest edited by Alec Vahanian, MD, PhD; Department of Cardiology, Hôpital Bichat-Claude Bernard, and University Paris VII, Paris, France.

\section{Conflict of interest statement}

G.G. Stefanini reports a research grant (to the institution) from Boston Scientific and speaker/consulting fees from B. Braun, Biosensors, and Boston Scientific. R.A. Byrne reports lecture fees from B. Braun Melsungen AG and Biotronik, and research funding to the institution of employment from Celonova Biosciences. D. Capodanno declares consulting honoraria from Abbott Vascular, Bayer and Daiichi Sankyo, and speaker fees from AstraZeneca, Biosensors, Bayer, Boehringer Ingelheim, Daiichi Sankyo, and Sanofi Aventis. E. Barbato declares speaker's fees from BSCI, Abbott Vascular, and GE. V. Kunadian reports consulting fees/ honoraria from Bayer, Amgen, Daiichi Sankyo, Abbott Vascular, and AstraZeneca, and a major institutional research grant from AstraZeneca. J. Mehilli reports personal fees from AstraZeneca, has received lecture fees from Abbott Vascular, Boston Scientific, Biotronik, Edwards Lifesciences, Bristol-Myers Squibb, Medtronic and Terumo, and has received institutional research grants from Edwards Lifesciences, Boston Scientific, and Abbott Vascular. D. Regazzoli reports speaker honoraria from Amgen and Boehringer. A. Baumbach reports institutional research support from Abbott Vascular and honoraria from AstraZeneca, Sinomed, MicroPort, Abbott Vascular, Cardinal Health, and KSH. F.J. Neumann reports 
personal fees from Amgen, Boehringer Ingelheim, and Daiichi Sankyo, grants and personal fees from Pfizer, Biotronik, Edwards Lifesciences, Bayer Healthcare, and Boston Scientific, personal fees from Novartis, grants from Medtronic, and GlaxoSmithKline, and personal fees from Ferrer, outside the submitted work. W. Wijns reports grants and personal fees from MicroPort, outside the submitted work, being a medical advisor to Rede Optimus Research, and being a co-founder of Argonauts, an innovation facilitator. The other authors have no conflicts to declare. The Guest Editor is a consultant for Edwards Lifesciences.

\section{References}

1. Head SJ, Milojevic M, Taggart DP, Puskas JD. Current Practice of State-ofthe-Art Surgical Coronary Revascularization. Circulation. 2017;136:1331-45.

2. Stefanini GG, Holmes DR. Drug-eluting coronary-artery stents. $N$ Engl $J$ Med. 2013;368:254-65.

3. Byrne RA, Serruys PW, Baumbach A, Escaned J, Fajadet J, James S, Joner M, Oktay S, Jüni P, Kastrati A, Sianos G, Stefanini GG, Wijns W, Windecker S. Report of a European Society of Cardiology-European Association of Percutaneous Cardiovascular Interventions task force on the evaluation of coronary stents in Europe: executive summary. Eur Heart J. 2015;36:2608-20.

4. Parasca CA, Head SJ, Milojevic M, Mack MJ, Serruys PW, Morice MC, Mohr FW, Feldman TE, Colombo A, Dawkins KD, Holmes DR Jr, Kappetein PA; SYNTAX Investigators. Incidence, Characteristics, Predictors, and Outcomes of Repeat Revascularization After Percutaneous Coronary Intervention and Coronary Artery Bypass Grafting: The SYNTAX Trial at 5 Years. JACC Cardiovasc Interv. 2016;9:2493-507.

5. Fosbøl EL, Zhao Y, Shahian DM, Grover FL, Edwards FH, Peterson ED. Repeat coronary revascularization after coronary artery bypass surgery in older adults. Circulation. 2013;127:1656-63.

6. Taniwaki M, Stefanini GG, Silber S, Richardt G, Vranckx P, Serruys PW, Buszman PE, Kelbaek H, Windecker S; RESOLUTE All-Comers Investigators. 4-year clinical outcomes and predictors of repeat revascularization in patients treated with new-generation drug-eluting stents: a report from the RESOLUTE All-Comers trial (A Randomized Comparison of a Zotarolimus-Eluting Stent With an Everolimus-Eluting Stent for Percutaneous Coronary Intervention). J Am Coll Cardiol. 2014;63:1617-25.

7. Giustino G, Serruys PW, Sabik JF 3rd, Mehran R, Maehara A, Puskas JD, Simonton CA, Lembo NJ, Kandzari DE, Morice M, Taggart DP, Gershlick AH, Ragosta M 3rd, Kron IL, Liu Y, Zhang Z, McAndrew T, Dressler O, Généreux P, Ben-Yehuda O, Pocock SJ, Kappetein AP, Stone GW. Mortality After Repeat Revascularization Following PCI or Coronary Artery Bypass Grafting for Left Main Disease: The EXCEL trial. JACC Cardiovasc Interv. 2020;13:375-87.

8. Arnold SV, Magnuson EA, Wang K, Serruys PW, Kappetein AP, Mohr FW, Cohen DJ; SYNTAX Investigators. Do differences in repeat revascularization explain the antianginal benefits of bypass surgery versus percutaneous coronary intervention?: implications for future treatment comparisons. Circ Cardiovas Qual Outcomes. 2012;5:267-75.

9. Palmerini T, Della Riva D, Biondi-Zoccai G, Leon MB, Serruys PW, Smits PC, von Birgelen C, Ben-Yehuda O, Généreux P, Bruno AG, Jenkins P, Stone GW. Mortality Following Nonemergent, Uncomplicated Target Lesion Revascularization After Percutaneous Coronary Intervention: An Individual Patient Data Pooled Analysis of 21 Randomized Trials and 32,524 Patients. JACC Cardiovasc Interv. 2018;11:892-902.

10. Escaned J. Secondary coronary revascularisation: an emerging issue. EuroIntervention. 2009;5 Suppl D:D6-13.

11. Garcia-Garcia HM, McFadden EP, Farb A, Mehran R, Stone GW, Spertus J, Onuma Y, Morel M, van Es GA, Zuckerman B, Fearon WF, Taggart D,
Kappetein AP, Krucoff MW, Vranckx P, Windecker S, Cutlip D, Serruys PW; Academic Research Consortium. Standardized End Point Definitions for Coronary Intervention Trials: The Academic Research Consortium-2 Consensus Document. Eur Heart J. 2018;39:2192-207.

12. Byrne RA, Joner M, Kastrati A. Stent thrombosis and restenosis: what have we learned and where are we going? The Andreas Grüntzig Lecture ESC 2014 Eur Heart J. 2015;36:3320-31.

13. Adriaenssens T, Joner M, Godschalk TC, Malik N, Alfonso F, Xhepa E, De Cock D, Komukai K, Tada T, Cuesta J, Sirbu V, Feldman LJ, Neumann FJ, Goodall AH, Heestermans T, Buysschaert I, Hlinomaz O, Belmans A, Desmet W, Ten Berg JM, Gershlick AH, Massberg S, Kastrati A, Guagliumi G, Byrne RA; Prevention of Late Stent Thrombosis by an Interdisciplinary Global European Effort (PRESTIGE) Investigators. Optical Coherence Tomography Findings in Patients With Coronary Stent Thrombosis: A Report of the PRESTIGE Consortium (Prevention of Late Stent Thrombosis by an Interdisciplinary Global European Effort). Circulation. 2017;136:1007-21.

14. Neumann FJ, Sousa-Uva M, Ahlsson A, Alfonso F, Banning AP, Benedetto U, Byrne RA, Collet JP, Falk V, Head SJ, Jüni P, Kastrati A, Koller A, Kristensen SD, Niebauer J, Richter DJ, Seferović PM, Sibbing D, Stefanini GG, Windecker S, Yadav R, Zembala MO. 2018 ESC/EACTS Guidelines on myocardial revascularization. EuroIntervention. 2019;14:1435-534.

15. Ibanez B, James S, Agewall S, Antunes MJ, Bucciarelli-Ducci C, Bueno H, Caforio ALP, Crea F, Goudevenos JA, Halvorsen S, Hindricks G, Kastrati A, Lenzen MJ, Prescott E, Roffi M, Valgimigli M, Varenhorst C, Vranckx P, Widimský P; ESC Scientific Document Group. 2017 ESC Guidelines for the management of acute myocardial infarction in patients presenting with ST-segment elevation: The Task Force for the management of acute myocardial infarction in patients presenting with ST-segment elevation of the European Society of Cardiology (ESC). Eur Heart J. 2018;39:119-77.

16. Roffi M, Patrono C, Collet JP, Mueller C, Valgimigli M, Andreotti F, Bax JJ, Borger MA, Brotons C, Chew DP, Gencer B, Hasenfuss G, Kjeldsen K, Lancellotti P, Landmesser U, Mehilli J, Mukherjee D, Storey RF, Windecker S; ESC Scientific Document Group. 2015 ESC Guidelines for the management of acute coronary syndromes in patients presenting without persistent ST-segment elevation: Task Force for the Management of Acute Coronary Syndromes in Patients Presenting without Persistent ST-Segment Elevation of the European Society of Cardiology (ESC). Eur Heart J. 2016;37:267-315.

17. Souteyrand G, Amabile N, Mangin L, Chabin X, Meneveau N, Cayla G, Vanzetto G, Barnay P, Trouillet C, Rioufol G, Rangé G, Teiger E, Delaunay R, Dubreuil O, Lhermusier T, Mulliez A, Levesque S, Belle L, Caussin C, Motreff P; PESTO Investigators. Mechanisms of stent thrombosis analysed by optical coherence tomography: insights from the national PESTO French registry. Eur Heart J. 2016;37:1208-16.

18. Kim MS, Eng MH, Hudson PA, Garcia JA, Wink O, Messenger JC, Carroll JD. Coronary stent fracture: clinical use of image enhancement. JACC Cardiovasc Imaging. 2010;3:446-7.

19. Salazar C, Escaned J, Tirado G, Gonzalo N. Undilatable Calcific Coronary Stenosis Causing Stent Underexpansion and Late Stent Thrombosis: A Complex Scenario Successfully Managed With Intravascular Lithotripsy. JACC Cardiovasc Interv. 2019;12:1510-2.

20. Rajendran S, Parikh D, Shugman I, French JK, Juergens CP. High on treatment platelet reactivity and stent thrombosis. Heart Lung Circ. 2011;20:525-31.

21. Mega JL, Simon T, Collet JP, Anderson JL, Antman EM, Bliden K, Cannon CP, Danchin N, Giusti B, Gurbel P, Horne BD, Hulot JS, Kastrati A, Montalescot G, Neumann FJ, Shen L, Sibbing D, Steg PG, Trenk D, Wiviott SD, Sabatine MS. Reduced-function CYP2C19 genotype and risk of adverse clinical outcomes among patients treated with clopidogrel predominantly for PCI: a meta-analysis. JAMA. 2010;304:1821-30.

22. Dangas GD, Claessen BE, Mehran R, Xu K, Stone GW. Stent thrombosis after primary angioplasty for STEMI in relation to non-adherence to dual antiplatelet therapy over time: results of the HORIZONS-AMI trial. EuroIntervention. 2013;8:1033-9. 
23. Bonaca MP, Bhatt DL, Cohen M, Steg PG, Storey RF, Jensen EC, Magnani G, Bansilal S, Fish MP, Im K, Bengtsson O, Ophuis TO, Budaj A, Theroux P, Ruda M, Hamm C, Goto S, Spinar J, Nicolau JC, Kiss RG, Murphy SA, Wiviott SD, Held P, Braunwald E, Sabatine MS; PEGASUS-TIMI 54 Steering Committee and Investigators. Long-term use of ticagrelor in patients with prior myocardial infarction. $N$ Engl J Med. 2015;372:1791-800.

24. Mauri L, Kereiakes DJ, Yeh RW, Driscoll-Shempp P, Cutlip DE, Steg PG, Normand SL, Braunwald E, Wiviott SD, Cohen DJ, Holmes DR Jr, Krucoff MW, Hermiller J, Dauerman HL, Simon DI, Kandzari DE, Garratt KN, Lee DP, Pow TK, Ver Lee P, Rinaldi MJ, Massaro JM; DAPT Study Investigators. Twelve or 30 months of dual antiplatelet therapy after drug-eluting stents. N Engl J Med. 2014;371:2155-66.

25. Stefanescu Schmidt AC, Kereiakes DJ, Cutlip DE, Yeh RW, D’Agostino RB Sr, Massaro JM, Hsieh WH, Mauri L; DAPT Investigators. Myocardial Infarction Risk After Discontinuation of Thienopyridine Therapy in the Randomized DAPT Study (Dual Antiplatelet Therapy). Circulation. 2017;135: 1720-32.

26. Stone GW, Ellis SG, Colombo A, Dawkins KD, Grube E, Cutlip DE, Friedman M, Baim DS, Koglin J. Offsetting impact of thrombosis and restenosis on the occurrence of death and myocardial infarction after paclitaxel-eluting and bare metal stent implantation. Circulation. 2007;115:2842-7.

27. Alfonso F, Byrne RA, Rivero F, Kastrati A. Current treatment of in-stent restenosis. J Am Coll Cardiol. 2014;63:2659-73.

28. Kufner S, Joner M, Schneider S, Tölg R, Zrenner B, Repp J, Starkmann A, Xhepa E, Ibrahim T, Cassese S, Fusaro M, Ott I, Hengstenberg C, Schunkert H, Abdel-Wahab M, Laugwitz KL, Kastrati A, Byrne RA; ISAR-DESIRE 4 Investigators. Neointimal Modification With Scoring Balloon and Efficacy of Drug-Coated Balloon Therapy in Patients With Restenosis in Drug-Eluting Coronary Stents: A Randomized Controlled Trial. JACC Cardiovasc Interv. 2017;10:1332-40.

29. de la Torre Hernandez JM, Rumoroso JR, Subinas A, Gonzalo N, Ojeda S, Pan M, Martín Yuste V, Suárez A, Hernández F, Teruel L, Moreu J, Cubero JM, Cascón JD, Vinhas H, Lozano I, Moreiras JM, Pérez de Prado A, Goicolea J, Escaned J. Percutaneous intervention in chronic total coronary occlusions caused by in-stent restenosis: procedural results and long-term clinical outcomes in the TORO (Spanish registry of chronic TOtal occlusion secondary to an occlusive in-stent RestenOsis) multicentre registry, EuroIntervention. 2017;13:e219-26.

30. Azzalini L, Dautov R, Ojeda S, Benincasa S, Bellini B, Giannini F, Chavarría J, Pan M, Carlino M, Colombo A, Rinfret S. Procedural and LongTerm Outcomes of Percutaneous Coronary Intervention for In-Stent Chronic Total Occlusion. JACC Cardiovasc Interv. 2017;10:892-902.

31. Yin D, Maehara A, Mezzafonte S, Moses JW, Mintz GS, Shlofmitz RA. Excimer Laser Angioplasty-Facilitated Fracturing of Napkin-Ring Peri-Stent Calcium in a Chronically Underexpanded Stent: Documentation by Optical Coherence Tomography. JACC Cardiovasc Interv. 2015;8:e137-9.

32. Alfonso F, Bastante T, Antuña P, de la Cuerda F, Cuesta J, GarcíaGuimaraes M, Rivero F. Coronary Lithoplasty for the Treatment of Undilatable Calcified De Novo and In-Stent Restenosis Lesions. JACC Cardiovasc Interv. 2019;12:497-9.

33. Salazar C, Escaned J, Tirado G, Gonzalo N. Intravascular lithotripsy for recurrent restenosis caused by severe calcific neoatherosclerosis. EuroIntervention. 2020;16:e351-e352.

34. Akin I, Pohlmann S, Nienaber CA, Ince H. A different way of coronary lesion preparation: stentablation and rotastenting. Clin Med Insights Cardiol. 2012;6:53-6

35. Byrne RA, Neumann FJ, Mehilli J, Pinieck S, Wolff B, Tiroch K, Schulz S, Fusaro M, Ott I, Ibrahim T, Hausleiter J, Valina C, Pache J, Laugwitz KL, Massberg S, Kastrati A; ISAR-DESIRE 3 investigators. Paclitaxel-eluting balloons, paclitaxel-eluting stents, and balloon angioplasty in patients with restenosis after implantation of a drug-eluting stent (ISAR-DESIRE 3): a randomised, open-label trial. Lancet. 2013;381:461-7.
36. Siontis GC, Stefanini GG, Mavridis D, Siontis KC, Alfonso F, PérezVizcayno MJ, Byrne RA, Kastrati A, Meier B, Salanti G, Jüni P, Windecker S. Percutaneous coronary interventional strategies for treatment of in-stent restenosis: a network meta-analysis. Lancet. 2015;386:655-64.

37. Giacoppo D, Gargiulo G, Aruta P, Capranzano P, Tamburino C, Capodanno D. Treatment strategies for coronary in-stent restenosis: systematic review and hierarchical Bayesian network meta-analysis of 24 randomised trials and 4880 patients. BMJ. 2015;351:h5392.

38. Giacoppo D, Alfonso F, Xu B, Claessen BEPM, Adriaenssens T, Jensen C, Pérez-Vizcayno MJ, Kang DY, Degenhardt R, Pleva L, Baan J, Cuesta J, Park DW, Schunkert H, Colleran R, Kukla P, Jiménez-Quevedo P, Unverdorben M, Gao R, Naber CK, Park SJ, Henriques JPS, Kastrati A, Byrne RA. Paclitaxelcoated balloon angioplasty vs. drug-eluting stenting for the treatment of coronary in-stent restenosis: a comprehensive, collaborative, individual patient data meta-analysis of 10 randomized clinical trials (DAEDALUS study). Eur Heart $J$. 2020;41:3715-28.

39. Alfonso F, Pérez-Vizcayno MJ, García del Blanco B, Otaegui I, Masotti M, Zueco J, Veláquez M, Sanchís J, García-Touchard A, Lázaro-García R, Moreu J, Bethencourt A, Cuesta J, Rivero F, Cárdenas A, Gonzalo N, JiménezQuevedo P, Fernández C; RIBS V Study Investigators. Long-Term Results of Everolimus-Eluting Stents Versus Drug-Eluting Balloons in Patients With Bare-Metal In-Stent Restenosis: 3-Year Follow-Up of the RIBS V Clinical Trial. JACC Cardiovasc Interv. 2016;9:1246-55.

40. Alfonso F, Pérez-Vizcayno MJ, Cárdenas A, García del Blanco B, GarcíaTouchard A, López-Minguéz JR, Benedicto A, Masotti M, Zueco J, Iñiguez A, Velázquez M, Moreno R, Mainar V, Domínguez A, Pomar F, Melgares R, Rivero F, Jiménez-Quevedo P, Gonzalo N, Fernández C, Macaya C; RIBS IV Study Investigators (under auspices of Interventional Cardiology Working Group of Spanish Society of Cardiology). A Prospective Randomized Trial of Drug-Eluting Balloons Versus Everolimus-Eluting Stents in Patients With In-Stent Restenosis of Drug-Eluting Stents: The RIBS IV Randomized Clinical Trial. J Am Coll Cardiol. 2015;66:23-33.

41. Johnson TW, Räber L, di Mario C, Bourantas C, Jia H, Mattesini A, Gonzalo N, de la Torre Hernandez JM, Prati F, Koskinas K, Joner M, Radu MD, Erlinge D, Regar E, Kunadian V, Maehara A, Byrne RA, Capodanno D, Akasaka T, Wijns W, Mintz GS, Guagliumi G. Clinical use of intracoronary imaging. Part 2: acute coronary syndromes, ambiguous coronary angiography findings, and guiding interventional decision-making: an expert consensus document of the European Association of Percutaneous Cardiovascular Interventions. Eur Heart J. 2019;40:2566-84.

42. Räber L, Mintz GS, Koskinas KC, Johnson TW, Holm NR, Onuma Y, Radu MD, Joner M, Yu B, Jia H, Meneveau N, de la Torre Hernandez JM, Escaned J, Hill J, Prati F, Colombo A, di Mario C, Regar E, Capodanno D, Wijns W, Byrne RA, Guagliumi G; ESC Scientific Document Group. Clinical use of intracoronary imaging. Part 1: Guidance and optimization of coronary interventions. An expert consensus document of the European Association of Percutaneous Cardiovascular Interventions. Eur Heart J. 2018;39:3281-300.

43. Pijls NH, Klauss V, Siebert U, Powers E, Takazawa K, Fearon WF, Escaned J, Tsurumi Y, Akasaka T, Samady H, De Bruyne B; Fractional Flow Reserve (FFR) Post-Stent Registry Investigators. Coronary pressure measurement after stenting predicts adverse events at follow-up: a multicenter registry. Circulation. 2002;105:2950-4.

44. Agarwal SK, Kasula S, Hacioglu Y, Ahmed Z, Uretsky BF, Hakeem A. Utilizing Post-Intervention Fractional Flow Reserve to Optimize Acute Results and the Relationship to Long-Term Outcomes. JACC Cardiovasc Interv. 2016;9:1022-31.

45. Rimac G, Fearon WF, De Bruyne B, Ikeno F, Matsuo H, Piroth Z, Costerousse O, Bertrand OF. Clinical value of post-percutaneous coronary intervention fractional flow reserve value: A systematic review and meta-analysis. Am Heart J. 2017;183:1-9.

46. Wolfrum M, De Maria GL, Benenati S, Langrish J, Lucking AJ, Channon KM, Kharbanda RK, Banning AP. What are the causes of a subopti- 
mal FFR after coronary stent deployment? Insights from a consecutive series using OCT imaging. EuroIntervention. 2018;14:e1324-31.

47. Azzalini L, Poletti E, Demir OM, Ancona MB, Mangieri A, Giannini F, Carlino M, Chieffo A, Montorfano M, Colombo A, Latib A. Impact of PostPercutaneous Coronary Intervention Fractional Flow Reserve Measurement on Procedural Management and Clinical Outcomes: The REPEAT-FFR Study. J Invasive Cardiol. 2019;31:229-34.

48. Crea F, Bairey Merz CN, Beltrame JF, Berry C, Camici PG, Kaski JC, Ong P, Pepine CJ, Sechtem U, Shimokawa H. Mechanisms and diagnostic evaluation of persistent or recurrent angina following percutaneous coronary revascularization. Eur Heart J. 2019;40:2455-62.

49. Mehta RH, Ferguson TB, Lopes RD, Hafley GE, Mack MJ, Kouchoukos NT, Gibson CM, Harrington RA, Califf RM, Peterson ED, Alexander JH; Project of Ex-vivo Vein Graft Engineering via Transfection (PREVENT) IV Investigators. Saphenous vein grafts with multiple versus single distal targets in patients undergoing coronary artery bypass surgery: one-year graft failure and five-year outcomes from the Project of Ex-Vivo Vein Graft Engineering via Transfection (PREVENT) IV trial. Circulation. 2011;124:280-8.

50. Lamy A, Eikelboom J, Sheth T, Connolly S, Bosch J, Fox KAA, Zhu J, Lonn E, Dagenais G, Widimsky P, Branch KRH, Bhatt DL, Zheng Z, Straka Z, Dagenais F, Kong Y, Marsden T, Lee SF, Copland I, Yusuf S. Rivaroxaban, Aspirin, or Both to Prevent Early Coronary Bypass Graft Occlusion: The COMPASS-CABG Study. J Am Coll Cardiol. 2019;73:121-30.

51. Goldman S, Zadina K, Moritz T, Ovitt T, Sethi G, Copeland JG, Thottapurathu L, Krasnicka B, Ellis N, Anderson RJ, Henderson W; VA Cooperative Study Group \#207/297/364. Long-term patency of saphenous vein and left internal mammary artery grafts after coronary artery bypass surgery: results from a Department of Veterans Affairs Cooperative Study. J Am Coll Cardiol. 2004;44:2149-56.

52. Zhao DX, Leacche M, Balaguer JM, Boudoulas KD, Damp JA, Greelish JP, Byrne JG; Writing Group of the Cardiac Surgery, Cardiac Anesthesiology, and Interventional Cardiology Groups at the Vanderbilt Heart and Vascular Institute, Ahmad RM, Ball SK, Cleator JH, Deegan RJ, Eagle SS, Fong PP, Fredi JL, Hoff SJ, Jennings HS 3rd, McPherson JA, Piana RN, Pretorius M, Robbins MA, Slosky DA, Thompson A. Routine intraoperative completion angiography after coronary artery bypass grafting and 1-stop hybrid revascularization results from a fully integrated hybrid catheterization laboratory/operating room. J Am Coll Cardiol. 2009;53:232-41.

53. Yahagi K, Kolodgie FD, Otsuka F, Finn AV, Davis HR, Joner M, Virmani R. Pathophysiology of native coronary, vein graft, and in-stent atherosclerosis. Nat Rev Cardiol. 2016;13:79-98.

54. Harskamp RE, Lopes RD, Baisden CE, de Winter RJ, Alexander JH. Saphenous vein graft failure after coronary artery bypass surgery: pathophysiology, management, and future directions. Ann Surg. 2013;257:824-33.

55. Thielmann M, Massoudy P, Jaeger BR, Neuhäuser M, Marggraf G, Sack S, Erbel R, Jakob H. Emergency re-revascularization with percutaneous coronary intervention, reoperation, or conservative treatment in patients with acute perioperative graft failure following coronary artery bypass surgery. Eur $J$ Cardiothorac Surg. 2006;30:117-25.

56. Laflamme M, DeMey N, Bouchard D, Carrier M, Demers P, Pellerin M, Couture P, Perrault LP. Management of early postoperative coronary artery bypass graft failure. Interact Cardiovasc Thorac Surg. 2012;14:452-6.

57. Rasmussen C, Thiis JJ, Clemmensen P, Efsen F, Arendrup HC, Saunamäki K, Madsen JK, Pettersson G. Significance and management of early graft failure after coronary artery bypass grafting: feasibility and results of acute angiography and re-re-vascularization. Eur J Cardiothorac Surg. 1997;12:847-52.

58. Davierwala PM, Verevkin A, Leontyev S, Misfeld M, Borger MA, Mohr FW. Impact of expeditious management of perioperative myocardial ischemia in patients undergoing isolated coronary artery bypass surgery. Circulation. 2013;128:S226-34.
59. Biancari F, Anttila V, Dell'Aquila AM, Airaksinen JKE, Brascia D. Control angiography for perioperative myocardial Ischemia after coronary surgery: meta-analysis. J Cardiothorac Surg. 2018;13:24.

60. Alqahtani F, Ziada KM, Badhwar V, Sandhu G, Rihal CS, Alkhouli M. Incidence, Predictors, and Outcomes of In-Hospital Percutaneous Coronary Intervention Following Coronary Artery Bypass Grafting. $J$ Am Coll Cardiol. 2019;73:415-23.

61. Brilakis ES, Edson R, Bhatt DL, Goldman S, Holmes DR Jr, Rao SV, Shunk K, Rangan BV, Mavromatis K, Ramanathan K, Bavry AA, Garcia S, Latif F, Armstrong E, Jneid H, Conner TA, Wagner T, Karacsonyi J, Uyeda L, Ventura B, Alsleben A, Lu Y, Shih MC, Banerjee S; DIVA Trial Investigators. Drug-eluting stents versus bare-metal stents in saphenous vein grafts: a doubleblind, randomised trial. Lancet. 2018;391:1997-2007.

62. Mehilli J, Pache J, Abdel-Wahab M, Schulz S, Byrne RA, Tiroch K, Hausleiter J, Seyfarth M, Ott I, Ibrahim T, Fusaro M, Laugwitz KL, Massberg S, Neumann FJ, Richardt G, Schömig A, Kastrati A; Is Drug-Eluting-Stenting Associated with Improved Results in Coronary Artery Bypass Grafts? (ISARCABG) Investigators. Drug-eluting versus bare-metal stents in saphenous vein graft lesions (ISAR-CABG): a randomised controlled superiority trial. Lancet. 2011;378:1071-8.

63. Colleran R, Kufner S, Mehilli J, Rosenbeiger C, Schüpke S, Hoppmann P, Joner M, Mankerious N, Fusaro M, Cassese S, Abdel-Wahab M, Neumann FJ, Richardt G, Ibrahim T, Schunkert H, Laugwitz KL, Kastrati A, Byrne RA; ISAR-CABG Investigators. Efficacy Over Time With Drug-Eluting Stents in Saphenous Vein Graft Lesions. J Am Coll Cardiol. 2018;71:1973-82.

64. Garg A, Rout A, Tayal R, Sharma A, Agrawal S, Kostis JB, Cohen M, Sharma S, Wasty N. Drug-eluting Stents Versus Bare-metal Stents for Saphenous Vein Graft Interventions: A Systematic Review and Meta-analysis of Studies With Longer Follow-up. Curr Probl Cardiol. 2019 Jan 8. [Epub ahead of print].

65. Morrison DA, Sethi G, Sacks J, Henderson WG, Grover F, Sedlis S, Esposito R; Investigators of the Department of Veterans Affairs Cooperative Study \#385, Angina With Extremely Serious Operative Mortality Evaluation. Percutaneous coronary intervention versus repeat bypass surgery for patients with medically refractory myocardial ischemia: AWESOME randomized trial and registry experience with post-CABG patients. $\mathrm{J} \mathrm{Am} \mathrm{Coll} \mathrm{Cardiol.} \mathrm{2002;}$ 40:1951-4.

66. Brilakis ES, Rao SV, Banerjee S, Goldman S, Shunk KA, Holmes DR, Honeycutt E, Roe MT. Percutaneous coronary intervention in native arteries versus bypass grafts in prior coronary artery bypass grafting patients: a report from the National Cardiovascular Data Registry. JACC Cardiovasc Interv. 2011;4:844-50.

67. Naidu SS, Turco MA, Mauri L, Coolong A, Popma JJ, Kereiakes DJ. Contemporary incidence and predictors of major adverse cardiac events after saphenous vein graft intervention with embolic protection (an AMEthyst trial substudy). Am J Cardiol. 2010;105:1060-4.

68. Baim DS, Wahr D, George B, Leon MB, Greenberg J, Cutlip DE, Kaya U, Popma JJ, Ho KKL, Kuntz RE; Saphenous vein graft Angioplasty Free of Emboli Randomized (SAFER) Trial Investigators. Randomized trial of a distal embolic protection device during percutaneous intervention of saphenous vein aorto-coronary bypass grafts. Circulation. 2002;105:1285-90.

69. Dixon SR, Mann JT, Lauer MA, Casale PN, Dippel EJ, Strumpf RK, Feldman RL, Shear W, Resar JR, Zimmer SD, O'Neill WW; TRAP Investigators. A randomized, controlled trial of saphenous vein graft intervention with a filter-based distal embolic protection device: TRAP trial. $J$ Interv Cardiol. 2005;18:233-41.

70. Paul TK, Bhatheja S, Panchal HB, Zheng S, Banerjee S, Rao SV, Guzman L, Beohar N, Zhao D, Mehran R, Mukherjee D. Outcomes of Saphenous Vein Graft Intervention With and Without Embolic Protection Device: A Comprehensive Review and Meta-Analysis. Circ Cardiovasc Interv. 2017; 10:e05538. 
71. Brilakis ES, O’Donnell CI, Penny W, Armstrong EJ, Tsai T, Maddox TM, Plomondon ME, Banerjee S, Rao SV, Garcia S, Nallamothu B, Shunk KA, Mavromatis K, Grunwald GK, Bhatt DL. Percutaneous Coronary Intervention in Native Coronary Arteries Versus Bypass Grafts in Patients With Prior Coronary Artery Bypass Graft Surgery: Insights From the Veterans Affairs Clinical Assessment, Reporting, and Tracking Program. JACC Cardiovasc Interv. 2016;9:884-93.

72. Wang N, Fulcher J, Abeysuriya N, Adams M, Lal S. Predictors of successful chronic total occlusion percutaneous coronary interventions: a systematic review and meta-analysis. Heart. 2018;104:517-24.

73. Stone GW, Maehara A, Lansky AJ, de Bruyne B, Cristea E, Mintz GS, Mehran R, McPherson J, Farhat N, Marso SP, Parise H, Templin B, White R, Zhang Z, Serruys PW; PROSPECT Investigators. A prospective natural-history study of coronary atherosclerosis. N Engl J Med. 2011;364:226-35.

74. Taniwaki M, Windecker S, Zaugg S, Stefanini GG, Baumgartner S, Zanchin T, Wenaweser P, Meier B, Jüni P, Räber L. The association between in-stent neoatherosclerosis and native coronary artery disease progression: a long-term angiographic and optical coherence tomography cohort study. Eur Heart J. 2015;36:2167-76.

75. Cashin WL, Sanmarco ME, Nessim SA, Blankenhorn DH. Accelerated progression of atherosclerosis in coronary vessels with minimal lesions that are bypassed. N Engl J Med. 1984;311:824-8.

76. Pereg D, Fefer P, Samuel M, Wolff R, Czarnecki A, Deb S, Sparkes JD, Fremes SE, Strauss BH. Native coronary artery patency after coronary artery bypass surgery. JACC Cardiovasc Interv. 2014;7:761-7.

77. Valgimigli M, Bueno H, Byrne RA, Collet JP, Costa F, Jeppsson A, Jüni P, Kastrati A, Kolh P, Mauri L, Montalescot G, Neumann FJ, Petricevic M, Roffi M, Steg PG, Windecker S, Zamorano JL, Levine GN; ESC Scientific Document Group; ESC Committee for Practice Guidelines (CPG); ESC National Cardiac Societies. 2017 ESC focused update on dual antiplatelet therapy in coronary artery disease developed in collaboration with EACTS: The Task Force for dual antiplatelet therapy in coronary artery disease of the European Society of Cardiology (ESC) and of the European Association for Cardio-Thoracic Surgery (EACTS). Eur Heart J. 2018;39:213-60.

78. Knuuti J, Wijns W, Saraste A, Capodanno D, Barbato E, Funck-Brentano C, Prescott E, Storey RF, Deaton C, Cuisset T, Agewall S, Dickstein K, Edvardsen T, Escaned J, Gersh BJ, Svitil P, Gilard M, Hasdai D, Hatala R, Mahfoud F, Masip J, Muneretto C, Valgimigli M, Achenbach S, Bax JJ; ESC Scientific Document Group. 2019 ESC Guidelines for the diagnosis and management of chronic coronary syndromes. Eur Heart J. 2020;41:407-77.

79. Mäkikallio T, Holm NR, Lindsay M, Spence MS, Erglis A, Menown IB, Trovik T, Eskola M, Romppanen H, Kellerth T, Ravkilde J, Jensen LO, Kalinauskas G, Linder RB, Pentikainen M, Hervold A, Banning A, Zaman A, Cotton J, Eriksen E, Margus S, Sørensen HT, Nielsen PH, Niemelä M, Kervinen K, Lassen JF, Maeng M, Oldroyd K, Berg G, Walsh SJ, Hanratty CG, Kumsars I, Stradins P, Steigen TK, Fröbert O, Graham AN, Endresen PC, Corbascio M, Kajander O, Trivedi U, Hartikainen J, Anttila V, Hildick-Smith D, Thuesen L, Christiansen EH; NOBLE study investigators. Percutaneous coronary angioplasty versus coronary artery bypass grafting in treatment of unprotected left main stenosis (NOBLE): a prospective, randomised, open-label, non-inferiority trial. Lancet. 2016;388:2743-52.

80. Stone GW, Sabik JF, Serruys PW, Simonton CA, Généreux P, Puskas J, Kandzari DE, Morice MC, Lembo N, Brown WM 3rd, Taggart DP, Banning A, Merkely B, Horkay F, Boonstra PW, van Boven AJ, Ungi I, Bogáts G, Mansour S, Noiseux N, Sabaté M, Pomar J, Hickey M, Gershlick A, Buszman P, Bochenek A, Schampaert E, Pagé P, Dressler O, Kosmidou I, Mehran R, Pocock SJ, Kappetein AP; EXCEL Trial Investigators. Everolimus-Eluting Stents or Bypass Surgery for Left Main Coronary Artery Disease. $N$ Engl $J$ Med. 2016;375:2223-35.

81. Kandzari DE, Mauri L, Koolen JJ, Massaro JM, Doros G, GarciaGarcia HM, Bennett J, Roguin A, Gharib EG, Cutlip DE, Waksman R; BIOFLOW V Investigators. Ultrathin, bioresorbable polymer sirolimus-eluting stents versus thin, durable polymer everolimus-eluting stents in patients undergoing coronary revascularisation (BIOFLOW V): a randomised trial. Lancet. 2017;390:1843-52.

82. Biancari F, Dalén M, Ruggieri VG, Demal T, Gatti G, Onorati F, Faggian G, Rubino AS, Maselli D, Gherli R, Salsano A, Saccocci M, Santarpino G, Nicolini F, Tauriainen T, De Feo M, Airaksinen J, Rosato S, Perrotti A, Mariscalco G. Prognostic Impact of Multiple Prior Percutaneous Coronary Interventions in Patients Undergoing Coronary Artery Bypass Grafting. $J$ Am Heart Assoc. 2018;7:e010089.

83. Escaned J. Secondary revascularization after CABG surgery. Nat Rev Cardiol. 2012;9:540-9.

84. Nashef SAM, Roques F, Sharples LD, Nilsson J, Smith C, Goldstone AR, Lockowandt U. EuroSCORE II. Eur J Cardiothorac Surg. 2012;41:734-44.

85. Brener SJ, Lytle BW, Casserly IP, Ellis SG, Topol EJ, Lauer MS. Predictors of revascularization method and long-term outcome of percutaneous coronary intervention or repeat coronary bypass surgery in patients with multivessel coronary disease and previous coronary bypass surgery. Eur Heart J. 2006;27:413-8.

86. Serruys PW, Silber S, Garg S, van Geuns RJ, Richardt G, Buszman PE, Kelbæk H, van Boven AJ, Hofma SH, Linke A, Klauss V, Wijns W, Macaya C, Garot P, DiMario C, Manoharan G, Kornowski R, Ischinger T, Bartorelli A, Ronden J, Bressers M, Gobbens P, Negoita M, van Leeuwen F, Windecker S. Comparison of zotarolimus-eluting and everolimus-eluting coronary stents. $N$ Engl J Med. 2010;363:136-46.

87. Silber PS, Windecker PS, Vranckx P, Serruys PW; RESOLUTE All Comers investigators. Unrestricted randomised use of two new generation drug-eluting coronary stents: 2-year patient-related versus stent-related outcomes from the RESOLUTE All Comers trial. Lancet. 2011;377:1241-7.

88. von Birgelen C, Sen H, Lam MK, Danse PW, Jessurun GA, Hautvast RW, van Houwelingen GK, Schramm AR, Tjon Joe Gin RM, Louwerenburg JW, de Man FH, Stoel MG, Löwik MM, Linssen GC, Saïd SA, Nienhuis MB, Verhorst PM, Basalus MW, Doggen CJ, Tandjung K. Third-generation zotarolimus-eluting and everolimus-eluting stents in all-comer patients requiring a percutaneous coronary intervention (DUTCH PEERS): a randomised, single-blind, multicentre, non-inferiority trial. Lancet. 2014;383:413-23.

89. Sen H, Lam MK, Löwik MM, Danse PW, Jessurun GA, van Houwelingen KG, Anthonio RL, Tjon Joe Gin RM, Hautvast RW, Louwerenburg JH, de Man FH, Stoel MG, van der Heijden LC, Linssen GC, IJzerman MJ, Tandjung K, Doggen CJ, von Birgelen C. Clinical Events and Patient-Reported Chest Pain in All-Comers Treated With Resolute Integrity and Promus Element Stents: 2-Year Follow-Up of the DUTCH PEERS (DUrable Polymer-Based STent CHallenge of Promus ElemEnt Versus ReSolute Integrity) Randomized Trial (TWENTE II). JACC Cardiovasc Interv. 2015;8:889-99.

90. Zocca P, Kok MM, Tandjung K, Danse PW, Jessurun GAJ, Hautvast RWM, van Houwelingen KG, Stoel MG, Schramm AR, Tjon Joe Gin RM, de Man FHAF, Hartmann M, Louwerenburg JHW, Linssen GCM, Löwik MM, Doggen CJM, von Birgelen C. 5-Year Outcome Following Randomized Treatment of All-Comers With Zotarolimus-Eluting Resolute Integrity and Everolimus-Eluting PROMUS Element Coronary Stents: Final Report of the DUTCH PEERS (TWENTE II) Trial. JACC Cardiovasc Interv. 2018;11:462-9.

91. Saito S, Valdes-Chavarri M, Richardt G, Moreno R, Iniguez Romo A, Barbato E, Carrie D, Ando K, Merkely B, Kornowski R, Eltchaninoff H, James S, Wijns W; CENTURY II Investigators. A randomized, prospective, intercontinental evaluation of a bioresorbable polymer sirolimus-eluting coronary stent system: the CENTURY II (Clinical Evaluation of New Terumo Drug-Eluting Coronary Stent System in the Treatment of Patients With Coronary Artery Disease) Trial. Eur Heart J. 2014;35:2021-31.

92. Wijns W, Valdes-Chavarri M, Richardt G, Moreno R, Íñiguez-Romo A, Barbato E, Carrié D, Ando K, Merkely B, Kornowski R, Eltchaninoff H, Stojkovic S, Saito S. Long-term clinical outcomes after bioresorbable and 
permanent polymer drug-eluting stent implantation: final five-year results of the CENTURY II randomised clinical trial. EuroIntervention. 2018;14: e343-51.

93. Pilgrim T, Heg D, Roffi M, Tüller D, Muller O, Vuilliomenet A, Cook S, Weilenmann D, Kaiser C, Jamshidi P, Fahrni T, Moschovitis A, Noble S, Eberli RF, Wenaweser P, Jüni P, Windecker S. Ultrathin strut biodegradable polymer sirolimus-eluting stent versus durable polymer everolimus-eluting stent for percutaneous coronary revascularisation (BIOSCIENCE): a randomised, single-blind, non-inferiority trial. Lancet. 2014;384:2111-22.

94. Zbinden R, Piccolo R, Heg D, Roffi M, Kurz DJ, Muller O, Vuilliomenet A, Cook S, Weilenmann D, Kaiser C, Jamshidi P, Franzone A, Eberli F, Jüni P, Windecker S, Pilgrim T. Ultrathin Strut Biodegradable Polymer SirolimusEluting Stent Versus Durable-Polymer Everolimus-Eluting Stent for Precutaneous Coronary Revascularization: 2-Year Results of the BIOSCIENCE Trial. J Am Heart Assoc. 2016;5:e003255.

95. Pilgrim T, Piccolo R, Heg D, Roffi M, Tüller D, Muller O, Moarof I, Siontis GCM, Cook S, Weilenmann D, Kaiser C, Cuculi F, Hunziker L, Eberli FR, Jüni P, Windecker S. Ultrathin-strut, biodegradable-polymer, sirolimus-eluting stents versus thin-strut, durable-polymer, everolimus-eluting stents for percutaneous coronary revascularisation: 5-year outcomes of the BIOSCIENCE randomised trial. Lancet. 2018;392:737-46.

96. von Birgelen C, Kok MM, van der Heijden LC, Danse PW, Schotborgh CE, Scholte M, Gin RMTJ, Somi S, van Houwelingen KG, Stoel MG, de Man FHAF, Louwerenburg JHW, Hartmann M, Zocca P, Linssen GCM, van der Palen J, Doggen CJM, Löwik MM. Very thin strut biodegradable polymer everolimuseluting and sirolimus-eluting stents versus durable polymer zotarolimus-eluting stents in allcomers with coronary artery disease (BIO-RESORT): a three-arm, randomised, non-inferiority trial. Lancet. 2016;388:2607-17.

97. Kok MM, Zocca P, Buiten RA, Danse PW, Schotborgh CE, Scholte M, Hartmann M, Stoel MG, van Houwelingen G, Linssen GCM, Doggen CJM, von Birgelen C. Two-year clinical outcome of all-comers treated with three highly dissimilar contemporary coronary drug-eluting stents in the randomised BIO-RESORT trial. EuroIntervention. 2018;14:915-23.

98. Buiten RA, Ploumen EH, Zocca P, Doggen CJM, Danse PW, Schotborgh CE, Scholte M, van Houwelingen KG, Stoel MG, Hartmann M, Tjon Joe Gin RM, Somi S, Linssen GCM, Kok MM, von Birgelen C. Thin, Very Thin, or Ultrathin Strut Biodegradable or Durable Polymer-Coated Drug-Eluting Stents: 3-Year Outcomes of BIO-RESORT. JACC Cardiovasc Interv. 2019;12:1650-60.

99. Jensen LO, Thayssen P, Maeng M, Ravkilde J, Krusell LR, Raungaard B, Junker A, Terkelsen CJ, Veien KT, Villadsen AB, Kaltoft A, Tilsted HH, Hansen KN, Aaroe J, Kristensen SD, Hansen HS, Jensen SE, Madsen M, Bøtker HE, Berencsi K, Lassen JF, Christiansen EH. Randomized Comparison of a Biodegradable Polymer Ultrathin Strut Sirolimus-Eluting Stent With a Biodegradable Polymer Biolimus-Eluting Stent in Patients Treated With Percutaneous Coronary Intervention: The SORT OUT VII Trial. Circ Cardiovasc Interv. 2016;9:e03610.

100. Jensen LO, Maeng M, Raungaard B, Hansen KN, Kahlert J, Jensen SE, Hansen HS, Lassen JF, Bøtker HE. Two-year outcome after biodegradable polymer sirolimus- and biolimus-eluting coronary stents (from the randomised SORT OUT VII trial). EuroIntervention. 2018;13:1587-90.

101. Kandzari DE, Smits PC, Love MP, Ben-Yehuda O, Banai S, Robinson SD, Jonas M, Kornowski R, Bagur R, Iñiguez A, Danenberg H, Feldman R, Jauhar R, Chandna H, Parikh M, Perlman GY, Balcells M, Markham P, Ozan MO, Genereux P, Edelman ER, Leon MB, Stone GW. Randomized Comparison of Ridaforolimus-Eluting and Zotarolimus-Eluting Coronary Stents in Patients with Coronary Artery Disease: Primary Results from the BIONICS Trial (BioNIR Ridaforolimus-Eluting Coronary Stent System in Coronary Stenosis). Circulation. 2017;136:1304-14.

102. von Birgelen C, Zocca P, Buiten RA, Jessurun GAJ, Schotborgh CE, Roguin A, Danse PW, Benit E, Aminian A, van Houwelingen KG, Anthonio RL,
Stoel MG, Somi S, Hartmann M, Linssen GCM, Doggen CJM, Kok MM. Thin composite wire strut, durable polymer-coated (Resolute Onyx) versus ultrathin cobalt-chromium strut, bioresorbable polymer-coated (Orsiro) drug-eluting stents in allcomers with coronary artery disease (BIONYX): an international, single-blind, randomised non-inferiority trial. Lancet. 2018;392:1235-45.

103. Maeng M, Christiansen EH, Raungaard B, Kahlert J, Terkelsen CJ, Kristensen SD, Carstensen S, Aarøe J, Jensen SE, Villadsen AB, Lassen JF, Thim T, Eftekhari A, Veien KT, Hansen KN, Junker A, Bøtker HE, Jensen LO; SORT OUT VIII Investigators. Everolimus-Eluting Versus Biolimus-Eluting Stents With Biodegradable Polymers in Unselected Patients Undergoing Percutaneous Coronary Intervention: A Randomized Noninferiority Trial With 1-Year Follow-Up (SORT OUT VIII Trial). JACC Cardiovasc Interv. 2019;12: 624-33.

104. Geisler T, Zürn C, Simonenko R, Rapin M, Kraibooj H, Kilias A, Bigalke B, Stellos K, Schwab M, May AE, Herdeg C, Gawaz M. Early but not late stent thrombosis is influenced by residual platelet aggregation in patients undergoing coronary interventions. Eur Heart J. 2010;31:59-66.

105. Waksman R, Kirtane AJ, Torguson R, Cohen DJ, Ryan T, Räber L, Applegate R, Waxman S, Gordon P, Kaneshige K, Leon MB; DESERT Investigators. Correlates and outcomes of late and very late drug-eluting stent thrombosis: results from DESERT (International Drug-Eluting Stent Event Registry of Thrombosis). JACC Cardiovasc Interv. 2014;7:1093-102.

106. Taniwaki M, Radu MD, Zaugg S, Amabile N, Garcia-Garcia HM, Yamaji K, Jørgensen E, Kelbæk H, Pilgrim T, Caussin C, Zanchin T, Veugeois A, Abildgaard U, Jüni P, Cook S, Koskinas KC, Windecker S, Räber L. Mechanisms of Very Late Drug-Eluting Stent Thrombosis Assessed by Optical Coherence Tomography. Circulation. 2016;133:650-60.

107. Cassese S, Byrne RA, Tada T, Pinieck S, Joner M, Ibrahim T, King LA, Fusaro M, Laugwitz KL, Kastrati A. Incidence and predictors of restenosis after coronary stenting in 10004 patients with surveillance angiography. Heart. 2014;100:153-9.

108. Cayla G, Hulot JS, O'Connor SA, Pathak A, Scott SA, Gruel Y, Silvain J, Vignalou JB, Huerre Y, de la Briolle A, Allanic F, Beygui F, Barthélémy O, Montalescot G, Collet JP. Clinical, angiographic, and genetic factors associated with early coronary stent thrombosis. JAMA. 2011;306:1765-74.

109. Kuramitsu S, Ohya M, Shinozaki T, Otake H, Horie K, Kawamoto H, Yamanaka F, Natsuaki M, Shiomi H, Nakazawa G, Ando K, Kadota K, Saito S, Kimura T. Risk Factors and Long-Term Clinical Outcomes of SecondGeneration Drug-Eluting Stent Thrombosis. Circ Cardiovasc Interv. 2019;12: e007822.

110. Mehran R, Dangas G, Abizaid AS, Mintz GS, Lansky AJ, Satler LF, Pichard AD, Kent KM, Stone GW, Leon MB. Angiographic patterns of in-stent restenosis: classification and implications for long-term outcome. Circulation. 1999;100:1872-8.

111. Garcia-Guimaraes M, Antuña P, Maruri-Sanchez R, Vera A, Cuesta J, Bastante T, Rivero F, Alfonso F. Calcified neoatherosclerosis causing in-stent restenosis: prevalence, predictors, and implications. Coron Artery Dis. 2019;30:1-8.

112. Joner M, Koppara T, Byrne RA, Castellanos MI, Lewerich J, Novotny J, Guagliumi G, Xhepa E, Adriaenssens T, Godschalk TC, Malik N, Alfonso F, Tada T, Neumann FJ, Desmet W, Ten Berg JM, Gershlick AH, Feldman LJ, Massberg S, Kastrati A; Prevention of PRESTIGE Investigators. Neoatherosclerosis in Patients With Coronary Stent Thrombosis: Findings From Optical Coherence Tomography Imaging (A Report of the PRESTIGE Consortium). JACC Cardiovasc Interv. 2018;11:1340-50.

113. Xhepa E, Byrne RA, Rivero F, Rroku A, Cuesta J, Ndrepepa G, Kufner S, Valiente TB, Cassese S, Garcia-Guimaraes M, Lahmann AL, Rai H, Schunkert H, Joner M, Pérez-Vizcayno MJ, Gonzalo N, Alfonso F, Kastrati A. Qualitative and quantitative neointimal characterization by optical coherence tomography in patients presenting with in-stent restenosis. Clin Res Cardiol. 2019;108:1059-68. 